\title{
The Case Against the Goldstone Report: A Study in Evidentiary Bias
}

\section{Citation}

Alan Dershowitz, The Case Against the Goldstone Report: A Study in Evidentiary Bias.

\section{Permanent link}

http://nrs.harvard.edu/urn-3:HUL.InstRepos:3593975

\section{Terms of Use}

This article was downloaded from Harvard University's DASH repository, and is made available under the terms and conditions applicable to Other Posted Material, as set forth at http:// nrs.harvard.edu/urn-3:HUL.InstRepos:dash.current.terms-of-use\#LAA

\section{Share Your Story}

The Harvard community has made this article openly available. Please share how this access benefits you. Submit a story. 


\section{The Case Against the Goldstone Report: A Study in Evidentiary Bias By Alan Dershowitz ${ }^{1}$}

\section{INTRODUCTION}

The Goldstone Report, when read in full and in context, is much worse than most of its detractors (and supporters) believe. It is far more accusatory of Israel, far less balanced in its criticism of Hamas, far less honest in its evaluation of the evidence, far less responsible in drawing its conclusion, far more biased against Israeli than Palestinian witnesses, and far more willing to draw adverse inferences of intentionality from Israeli conduct and statements than from comparable Palestinian conduct and statements. It is worse than any report previously prepared by any other United Nations agency or human rights group. As Major General Avichai Mandelblit, the advocate general of the Israeli Defense Forces, aptly put it:

"I have read every report, from Human Rights Watch, Amnesty International, the Arab League. We ourselves set up investigations into 140 complaints. It is when you read these other reports and complaints that you realize how truly vicious the Goldstone report is. He made it look like we set out to go after the economic infrastructure and civilians, that it was intentional: It's a vicious lie."2

The Goldstone report is, to any fair reader, a shoddy piece of work, unworthy of serious consideration by people of good will, committed to the truth.

Most of the criticism and praise of the report has been based on its highly publicized and controversial conclusions, rather than on its methodology, analysis and substantive findings. The one statement Richard Goldstone has made, with which I agree, is that many of the report's most strident critics have probably not read the entire report. But it is also true, though I have not heard the report's biased author say this, that many of the report's most vocal defenders and advocates have also not read it.

It is not surprising that so few of the report's critics and supporters have actually made their way through its dense and repetitive texts. The version I originally read was 553 pages long plus appendices. There are 1223 footnotes, though many of its most critical statements are not well sourced. It is poorly written, obviously drafted by several different hands and without the benefit of a good overall editor. It is laden with internal inconsistencies, shoddy citations of authority, and overall poor craftsmanship. If a camel is a horse designed by a committee, this report lacks even the grace of a dromedary. Most of the commentary on the report, both pro and con, seems to be based on its somewhat sanitized summary and conclusion. Some of the worst mistakes are buried very deep in the report, many of the most serious ones toward the end.

\footnotetext{
${ }^{1}$ The author wishes to express great appreciation to Josh Sharp, who provided excellent research for this paper.

${ }^{2}$ Ethan Bronner, Israel Poised to Challenge a U.N. Report on Gaza, New York TiMES, Jan. 23, 2010, available at http://www.nytimes.com/2010/01/24/world/middleeast/24goldstone.html.
} 
Efforts are currently underway by supporters of the report to have governments, prosecutors, non-governmental organizations, religious groups and distinguished individuals sign on to the report, so as to give it the credibility it now lacks. No one should do so without reading the report in full—and without reading responsible criticisms (and defenses) of the report. I have read every word of the report and compared different sections. I have offered to debate Goldstone about its contents. He has refused, as he has generally refused to respond substantively to credible critics of the report. My offer to debate still stands. If he refuses, as I expect he will, let him at least respond to the serious legal, factual and moral criticisms contained in this study and others. ${ }^{3}$ As the head of the mission and the report's most visible public defender, Goldstone has a public obligation to respond to responsible criticism, which to date, he has not done.

In the coming week, the Secretary-General of the United Nations will present a compilation of responses to the Goldstone Report. ${ }^{4}$ I am submitting this analysis for inclusion.

The Israeli military will soon publish a detailed rebuttal to the Goldstone Report, providing photographic and other hard evidence that contradicts its most serious "findings." I am not in a position to deal with specific military issues. But I am in a position to consider and evaluate the evidentiary methodology employed by the Goldstone Report.

In this analysis, I will focus on the two central conclusions reached in the report. The first is that the real purpose of Operation Cast Lead was not to protect Israeli civilians from Hamas rockets, over eight thousand of which had struck Israel over a nine year period. ${ }^{5}$ According to the report, Israel used the rocket attacks on its citizens as a pretext, an excuse, a cover for the real purpose of the operation, which was to target innocent Palestinian civilians — children, women, the elderly — for death. This criminal objective was explicitly decided upon by the highest levels of the Israeli government and military and constitutes a deliberate and willful war crime. The report found these serious charges "to be firmly based in fact" and had "no doubt" of their truth. ${ }^{6}$

\footnotetext{
${ }^{3}$ Goldstone has said, "I have yet to hear from the Obama administration what the flaws in the report that they have identified are. I would be happy to respond to them, if and when I know what they are." Goldstone Tells Obama: Show Me Flaws in Gaza Report, HAARETZ, Nov. 22, 2009, available at http://www.haaretz.com/hasen/spages/1122893.html. Yet Goldstone has repeatedly failed to respond to substantive criticism of the report. The Committee for Accuracy in Middle East Reporting in America wrote Justice Goldstone a thoughtful letter containing substantive critiques and pointing out the report's flaws. A lengthy study of the report was attached. Here is how Goldstone responded: "I confirm receipt of your letter. I have no intention of responding to your open letter." A Formal Letter to Justice Goldstone, available at http://www.camera.org/index.asp?x_context $=7 \& \mathrm{x}$ issue $=76 \& \mathrm{x}$ _article $=1764$.

${ }^{4}$ Israel Official Reply on Goldstone Gaza Report: Probe Biased, Flawed, HAARETZ, Jan. 24, 2009, available at http://haaretz.com/hasen/spages/1144596.html.

${ }^{5}$ HUMAN RighTS WATCH, ROCKETS FROM GAZA 20 (Aug. 2009), available at http://www.hrw.org/sites/default/files/reports/ioptqassam0809web.pdf.

${ }^{6}$ U.N. Human Rights Council, Fact-Finding Mission on the Gaza Conflict, Human Rights in Palestine and Other Occupied Arab Territories, 1 甲 1884, 1895, U.N. Doc. A/HRC/12/48 (Sept. 25, 2009) [hereinafter Goldstone Report].
} 
In contrast, the Mission decided that Hamas was not guilty of deliberately and willfully using the civilian population as human shields. It found "no evidence" that Hamas fighters "engaged in combat in civilian dress," "no evidence" that "Palestinian combatants mingled with the civilian population with the intention of shielding themselves from attack," and no support for the claim that mosques were used to store weapons. ${ }^{7}$

As we will see, the report is demonstrably wrong about both of these critical conclusions. The hard evidence conclusively proves that the exact opposite is true, namely that:

1. Israel did not have a policy of targeting innocent civilians for death. Indeed the IDF went to unprecedented lengths to minimize civilian casualties; and

2. That Hamas did have a deliberate policy of having its combatants dress in civilian clothing, fire their rockets from densely populated areas, use civilians as human shields, and store weapons in mosques.

What is even more telling than its erroneous conclusions, however, is its deliberately skewed methodology, ${ }^{8}$ particularly the manner in which it used and evaluated similar evidence very differently, depending on whether it favored the Hamas or Israeli side.

The evidentiary bias of the report should come as no surprise to anyone who is familiar with the members of the Mission and statements they have made both before, during and after working on the report. ${ }^{9}$ There were four members: A Pakistani woman, who was formerly Special Representative of the Secretary-General on Human Rights Defenders; an Irish man, who was formerly a Colonel in the Irish Defense Forces; a British woman, who is a professor at the London School of Economics; and a South African man, the former Chief Prosecutor of the International Criminal Tribunals for the former Yugoslavia and Rwanda.

\footnotetext{
${ }^{7}$ Goldstone Report 9 甲 495, 483, 486.

${ }^{8}$ As a preliminary example of the Mission's skewed methodology, the Mission fails to verify the claims of Palestinian witnesses. For instance, Armr Hamad told the Mission, "The industrial sector that was destroyed, for example, the 324 factories that were destroyed, that we[re] destroyed used to employ fourhundred thous-, uh, 40,000 workers. And these have lost their uh, jobs, uh, forever." The witness based his testimony on a report that noted that only 4,000 workers lost their job, but the Mission blindly wrote, "Mr. Amr Hamad indicated that 324 factories had been destroyed during the Israeli military operations at a cost of 40,000 jobs.” See Richard Landes, Goldstone's Gaza Report: Part I, MIDDLE EAST REVIEW OF INTERNATIONAL AFFAIRS, Dec. 2009, available at http://www.gloriacenter.org/meria/2009/12/landes1.html\#_edn51 [hereinafter Goldstone's Gaza Report: Part I].

${ }^{9}$ It should also come as no surprise to anyone familiar with the workings of the United Nations Human Rights Council. By the time the UNHRC was only three years old, it had condemned Israel 26 times and all other nations 6 times total. Israel is the only country that is permanently on the agenda of the UNHRC. Richard Landes, Goldstone's Gaza Report: Part II, MidDle EAST ReVIEW Of InTERnational AfFairs, Dec. 2009, available at http://www.gloria-center.org/meria/2009/12/landes1.html\#_edn51 [hereinafter Goldstone's Gaza Report: Part II].
} 
The Pakistani member of the Mission, Hina Jilani, signed a letter (along with two other Mission members) before even being appointed stating that "The events in Gaza have shocked us to the core." ${ }^{10}$ After the report was completed, she made statements indicating that victims must not only be listened to, but that it would be "very cruel to not give credence to their voices." witnesses were monitored and controlled by Hamas, since their testimony was televised, and that much of it was demonstrably false and contradicted by hard evidence.

The Irish member of the Mission, Col. Desmond Travers, refused to believe evidence that undercut Hamas' position even when it was on videotape and utterly uncontradicted. This is what he said about weapons being stored in Gaza mosques: "We also found no evidence that mosques were used to store munitions. Those charges reflect Western perceptions in some quarters that Islam is a violent religion....If I were a Hamas operative the last place I'd store munitions would be in a mosque. It's not secure, is very visible, and would probably be pre-targeted by Israeli surveillance. There are a [sic] many better places to store munitions." 12 Not only is there physical evidence that conclusively proves that mosques are a favorite place to store rockets and other weapons, but Hamas leaders boast of it.

The British member, Christine Chinkin, had already decided the case before hearing one bit of evidence. Here is what she said in a letter that bore her signature written before she was even appointed to the Mission: "The rocket attacks on Israel by Hamas deplorable as they are, do not, in terms of scale and effect amount to an armed attack entitling Israel to rely on self-defence.... The killing of almost 800 Palestinians, mostly civilians, and more than 3,000 injuries, accompanied by the destruction of schools, mosques, houses, UN compounds and government buildings, which Israel has a responsibility to protect under the Fourth Geneva Convention, is not commensurate to the deaths caused by Hamas rocket fire....Israel's actions amount to aggression, not self-defence, not least because its assault on Gaza was unnecessary....As things stand, its invasion and bombardment of Gaza amounts to collective punishment of Gaza's $1.5 \mathrm{~m}$ inhabitants contrary to international humanitarian and human rights law.... [T] he manner and scale of its [Israel's] operations in Gaza amount to an act of aggression and is contrary to international law, notwithstanding the rocket attacks by Hamas." ${ }^{\text {"13 }}$ Here is the curious manner in which Goldstone responded to claims Chinkin was biased: "This is not a judicial inquiry. If it had been a judicial inquiry, that letter she'd signed would have been

\footnotetext{
${ }^{10}$ Gaza Investigators Call for War Crimes Inquiry, Amnesty International, Mar. 16, 2009, available at http://www.amnesty.org.au/news/comments/20572/.

${ }^{11}$ See Haroon Siddiqui, Looking for Accountability over Gaza War, THE STAR, Oct. 15, 2009, available at http://www.thestar.com/comment/article/710335 ("I think it was a very ill-considered move on his [Abbas's] part [to shelve the Goldstone Report]. I've been in Gaza. I've met the victims, as I've met the victims from southern Israel of rocket attacks from Hamas and other groups. And I know what the victims' expectations are. I think it'd be very cruel to not give credence to their voices.").

${ }^{12}$ Ken Silverstein, Six Questions for Desmond Travers on the Goldstone Report, HARPER's, Oct. 29, 2009, available at http://www.harpers.org/archive/2009/10/hbc-90006003.

${ }^{13}$ Israel's Bombardment of Gaza is Not Self-Defence - It's a War Crime, SUNDAY TIMES, Jan. 11, 2009, available at http://www.timesonline.co.uk/tol/comment/letters/article5488380.ece.
} 
a ground for disqualification." 14 If her bias would have been a ground for judicial disqualification, then surely her conclusions should not be credited by quasi-judicial bodies, such as the International Criminal Court, the U.N. Council on Human Rights and other governmental and non-governmental bodies.

Finally, the South African member, Richard Goldstone, insisted that the hearings in Gaza be televised, thereby assuring that all witnesses had to tow the Hamas party line or risk certain death. Goldstone also lied about the role Hamas played in escorting and presenting evidence to the Mission. Here is what Goldstone wrote about being escorted by Hamas: "I must, however, categorically deny the allegation that Hamas officials accompanied Members of the Fact Finding Mission at all, let alone 'at every stage of their visit to Gaza.' Reports to that effect are denial of truth, as I have already publically stated. I would have found this to be quite unacceptable." 15 The actual truth is quite different. According to an Associated Press article published on June 9, 2009, "Hamas security often accompanied his [Goldstone's] team during their five-day trip to Gaza last week, raising questions about the ability of witnesses to freely describe the militant group's actions." 16

How could Goldstone possibly know who among those escorting him were affiliated with Hamas? The reality is that nothing significant takes place in Gaza without the approval of Hamas.

Richard Goldstone has acknowledged that he accepted the role of Chairman with a clear preconceived agenda. ${ }^{17} \mathrm{He}$ has told numerous Jewish friends and acquaintances that he agreed to take on the task in order to "help Israel." He believed that he would bring "balance" to the report. Whether his real motive was to help Israel or to accomplish some other goal, it is always disqualifying to come to a quasi-judicial fact finding function with a preconceived agenda. Sometimes it causes one to lean over backwards, sometimes forwards. But leaning in either direction is inconsistent with objectivity.

\section{GOLDSTONE: ISRAEL INTENTIONALLY KILLS INNOCENT CIVILIANS}

I begin with the Mission's most irresponsible criticism of Israel. At bottom the report accuses the Jewish state of having implemented a policy in Gaza that borders on genocide. It blames the civilian deaths that occurred during Operation Cast Lead not on

\footnotetext{
${ }^{14}$ Goldstone Walks a Fine Line in an Ancient War Zone, BusINESS DAY (South Africa), Apr. 8, 2009, available at http://www.businessday.co.za/articles/Content.aspx?id=77618.

${ }^{15}$ Letter from Justice Richard Goldstone to Ambassador Leshno Yaar (July 17, 2009), available in the appendix to the Goldstone Report.

${ }^{16}$ Ben Hubbard, UN's Gaza War Crimes Investigation Faces Obstacles, Associated Press Wire, June 9 , 2009, available via the AP Archive at http://www.aparchive.com/. The AP has not retracted its statement, nor has Goldstone explicitly challenged it.

${ }^{17}$ Several other well known people, with a long history of antagonism to Israel, were originally asked to serve on the mission. They all declined. Mary Robinson, whose bias against Israel has been deep and longstanding, gave the following reason for declining the assignment: "[U]nfortunately, the Human Rights Council passed a resolution seeking a fact-finding mission to only look at what Israel had done, and I don't think that's a human rights approach." Quoted in Why Mary Robinson Rejected the Mandate Accepted by Judge Goldstone, U.N. Watch, available at http://blog.unwatch.org/?p=405.
} 
the fog of war, not on the use of human shields by Hamas, not on the inevitability of civilian casualties when rockets are fired from densely populated urban areas, not even on the use of "disproportionate force" by Israel. Instead it blames the Palestinian civilian deaths on an explicit policy devised at the highest levels of the Israeli government and military, of killing as many Palestinian civilians as possible. It concludes that Operation Cast Lead was not designed to stop the rocket attacks on Israel's civilians - more than eight thousand over a nine year period. ${ }^{18}$ Instead, the rocket attacks merely served as an excuse for the Israeli military to achieve its real purpose: namely the killing of Palestinian civilians. Lest there be any doubt that this is the accusation being made, read the words of the report itself:

"While the Israeli Government has sought to portray its operations as essentially a response to rocket attacks in the exercise of its right to self-defence, the Mission considers the plan to have been directed, at least in part, at a different target: the people of Gaza as a whole."19

At other points in the report, the language "at least in part" is dropped. Instead the report concludes that Israel's "overall policy [was] aimed at punishing the Gaza population" and that its "force [was] aimed not at the enemy," but at "the civilian population." 20 It found that Israel was guilty of "the direct targeting and arbitrary killing of Palestinian civilians" and that the killings "are the result of deliberate planning and policy decisions." 21 "[T]he Mission finds that the incident and patterns of events that are considered in this report have resulted from deliberate planning and policy decisions throughout the chain of command, down to the standard operating procedures and instructions given to the troops on the ground." "[I]n every case the Israeli armed forces had carried out direct intentional strikes against civilians," and the report considered that "the civilian population as such" was "the object of attacks," rather than the collateral victims of military actions directed against combatants. ${ }^{23}$

These are among the most serious charges ever leveled by a United Nations organization against a member state. It accuses Israel of using Hamas rocket attacks against its civilians as an excuse - a cover - for a carefully planned and executed policy of deliberately targeting innocent civilians for mass murder. As philosophy professor Moshe Halbertal, a strong peace advocate and frequent critic of Israeli military actions (including during Operation Cast Lead), put it:

"Now, there is a huge moral difference between the accusation that Israel did not do enough to minimize collateral civilian death and the claim that Israel targeted civilians intentionally. It might well be that Israel should have done more than it did to minimize collateral deaths - it is a harsh enough claim, and it deserves a

\footnotetext{
${ }^{18}$ HumAN RightS WATCH, RocKets From GAZA 20 (Aug. 2009), available at http://www.hrw.org/sites/default/files/reports/ioptqassam0809web.pdf.

${ }^{19}$ Goldstone Report 91883 . (emphasis added)

${ }^{20}$ Id. ๆ 1884, 1886.

${ }^{21} I d$. $₫ 816,61$.

${ }^{22}$ Id. 1191.

${ }^{23}$ Id. ๆๆ $810,841$.
} 
thorough examination. But the claim that Israel intentionally targeted civilians as a policy of war is false and slanderous." 24

Even Israel's most vociferous domestic critics - The Public Committee Against Torture in Israel and B'Tselem - acknowledge that "Israel did not have a policy of intentionally killing civilians...."25 Jessica Montell, Executive Director of B'Tselem, wrote, "I was disturbed by the framing of Israel's military operation as part of 'an overall policy aimed at punishing the Gaza population for its resilience.' The facts presented in the report itself would not seem to support such a far-reaching conclusion." 26 While condemning the operation as disproportionate, or worse, these organizations did not cross the "huge moral" line - the line irresponsibly and mendaciously crossed by the Goldstone Reportof accusing Israel of intentionally targeting civilians for death. As the New York Times reported:

"[V]irtually no one in Israel, including the leaders of Breaking the Silence and the human rights group B'Tselem, thinks that the Goldstone accusation of an assault on civilians is correct. 'I do not accept the Goldstone conclusion of a systematic attack of civilian infrastructure,' said Yael Stein, research director of B'Tselem. 'It is not convincing.,",27

One would expect that before making so serious and unprecedented a charge, the report would present overwhelming direct evidence of such a policy. Israel is, after all, an open society with an aggressive investigative media, a strong independent judiciary, many dissenting voices, vigorous opposition parties, a vibrant peace movement and few secrets. Yet the report presents absolutely no hard evidence to support its serious accusations of a governmental policy of deliberately maximizing civilian deaths.

Indeed, much of the evidence cited in the report proves precisely the opposite - that Israel's policy was to minimize civilian deaths, while attacking those responsible for targeting Israeli civilians with rocket attacks. Moreover, it ignores massive amounts of evidence - some specifically offered to it, other publicly available in open sources - that prove beyond any doubt that the central conclusions of the report are demonstrably false.

Goldstone has himself acknowledged that there is no actual "evidence" that the report's conclusions are correct. Indeed, he has gone even further and admitted that "If this was a court of law, there would have been nothing proven." He has also said he would not be embarrassed "if many of the allegations turn out to be disproved" 28 _as it appears likely

\footnotetext{
${ }^{24}$ Moshe Halbertal, The Goldstone Illusion, THE NEW REPUBLIC, Nov. 6, 2009, available at http://www.tnr.com/article/world/the-goldstone-illusion?page=0,5 [hereinafter The Goldstone Illusion].

${ }_{25}$ The Public COMmitTeE Against TORTURE In ISRAEL, No SECOND Thoughts 29 (Nov. 2009), available at http://www.stoptorture.org.il/files/no\%20second\%20thoughts_ENG_WEB.pdf.

${ }^{26}$ Jessica Montell, The Goldstone Report on Gaza, HufFInGTONPOST.COM, Oct. 1, 2009, available at http://www.huffingtonpost.com/jessica-montell/the-goldstone-report-on-g_b_306500.html.

${ }^{27}$ Ethan Bronner, Israel Poised to Challenge a U.N. Report on Gaza, NEW YORK TIMES, Jan. 23, 2010, available at http://www.nytimes.com/2010/01/24/world/middleeast/24goldstone.html.

${ }^{28}$ Gal Beckerman, Goldstone: 'If This Was a Court Of Law, There Would Have Been Nothing Proven', THE FORWARD, Oct. 16, 2009, available at http://www.forward.com/articles/116269/.
} 
they will be, by photographic and other hard evidence. ${ }^{29}$ Yet Israel's enemies cite the report as if it proved its charges beyond all doubt. That is because the report itself is written so as to suggest, quite falsely, that it had proved its case. For example:

"The Mission considers this position ["The operations were in furtherance of an overall policy aimed at punishing the Gaza population...."] to be firmly based in fact...."31

"[T]he systematic and deliberate nature of the activities described in this report leave the Mission in no doubt that responsibility lies in the first place with those who designed, planned, ordered and oversaw the operations." 32

The reality is that the report's central conclusions - that Israel's policy was to maximize the deaths of civilians - is not "firmly based in fact." It is made up of whole cloth and contradicted by the evidence purportedly relied on by those who wrote the report. Moreover, it is disproved by public record evidence deliberately ignored by the report. ${ }^{33}$

\footnotetext{
${ }^{29}$ Ethan Bronner, Israel Poised to Challenge a U.N. Report on Gaza, New YoRK TIMES, Jan. 23, 2010, available at http://www.nytimes.com/2010/01/24/world/middleeast/24goldstone.html.

${ }^{31}$ Goldstone Report 91884.

${ }^{32}$ Id. $\uparrow 1895$. According to The Forward:

"...the report itself is replete with bold and declarative legal conclusions seemingly at odds with the cautious and conditional explanations of its author. The report repeatedly refers, without qualification, to specific violations of the Fourth Geneva Convention committed by Israel and other breaches of international law. Citing particular cases, the report determines unequivocally that Israel 'violated the prohibition under customary international law' against targeting civilians. These violations, it declares, 'constitute a grave breach' of the convention."
}

Gal Beckerman, Goldstone: 'If This Was a Court Of Law, There Would Have Been Nothing Proven', THE FORWARD, Oct. 16, 2009, available at http://www.forward.com/articles/116269/.

Goldstone's claim that he "wouldn't consider it in any way embarrassing if many of the allegations turn out to be disproved," seems disingenuous, because Goldstone has put his imprimatur-and his reputationbehind the reports' conclusions. The only reason anyone is paying any attention to yet another of the serial condemnatory reports by the United Nations Human Rights Council is because Richard Goldstone - a "distinguished" Jew - allegedly wrote it and signed on to its conclusions. If he really doesn't stand by its conclusions - if he doesn't care one way or another whether they are true or false, proven or unproventhen no extra weight should be given to its findings or conclusions because of the "distinguished" reputation of its Jewish chairman. See Alan Dershowitz, Ad Hominem Attack on Israel, HUFFINGTONPOST.COM, Sept. 24, 2009, available at http://www.huffingtonpost.com/alan-dershowitz/adhominem-attack-on-isra_b_298681.html. But weight is being given to some of its "unproven" and uninvestigated allegations which Goldstone admits may be wrong. There have been calls for boycotts, divestments, war crime prosecutions and other forms of condemnation based on the conclusions reached by the report.

${ }^{33}$ Goldstone's content and tone varies, depending on his audience. When talking to largely Jewish audiences he minimizes the findings of the report, but when talking to other audiences, he maximizes them. Contrast his statement to The Forward, "And I wouldn't consider it in any way embarrassing if many of the allegations [in the report] turn out to be disproved" with what he told the Human Rights Council, "[W]e detail a number of specific incidents in which Israeli forces launched direct attacks against civilians with lethal consequences. These were, with only one exception, where the facts establish that there was no military objective or advantage that could justify the attacks." Gal Beckerman, Goldstone: 'If This Was a Court Of Law, There Would Have Been Nothing Proven', THE FORWARD, Oct. 16, 2009, available at http://www.forward.com/articles/116269/; Justice Richard Goldstone, Remarks before the U.N. Human Rights Council (prepared version) (Sept. 29, 2009), available at 
The report relies on five categories of evidence that purport to prove that Israel's true intention was not to defend its civilians against Hamas rocket attacks, but rather to maximize the deaths of innocent Palestinian civilians. These categories are: statements of military leaders; statements of political officials; the nature of Israeli weaponry; the number of civilian casualties; and the fact that the IDF deliberately attacked food supplies and non-human civilian targets, such as a wastewater plant.

The first category consists of statements - generally quoted with little or no contextmade by Israeli military leaders before the beginning of Operation Cast Lead. These include the following:

"In its operations in southern Lebanon in 2006, there emerged from Israeli military thinking a concept known as the Dahiya doctrine, as a result of the approach taken to the Beirut neighborhood of that name. Major General Gadi Eisenkot, the Israeli Northern Command chief, expressed the premise of the doctrine:

What happened in the Dahiya quarter of Beirut in 2006 will happen in every village from which Israel is fired on. [...] We will apply disproportionate force on it and cause great damage and destruction there. From our standpoint, these are not civilian villages, they are military bases. [...] This is not a recommendation. This is a plan. And it has been approved."

"After the war in southern Lebanon in 2006, a number of senior former military figures appeared to develop the thinking that underlay the strategy set out by Gen. Eiskenot. In particular Major General (Ret.) Giora Eiland has argued that, in the event of another war with Hizbullah, the target must not be the defeat of Hizbullah but 'the elimination of the Lebanese military, the destruction of the national infrastructure and intense suffering among the population... Serious damage to the Republic of Lebanon, the destruction of homes and infrastructure, and the suffering of hundreds of thousands of people are consequences that can influence Hizbollah's behavior more than anything else."”

"These thoughts, published in October 2008 were preceded by one month by the reflections of Col. (Ret.) Gabriel Siboni:

With an outbreak of hostilities, the IDF will need to act immediately, decisively, and with force that is disproportionate ${ }^{34}$ to the enemy's actions and the threat it poses. Such a response aims at inflicting damage and meting out punishment to an extent that will demand long and expensive reconstruction processes. The strike must be carried out as quickly as

http://www2.ohchr.org/english/bodies/hrcouncil/specialsession/9/docs/OpeningStatement_GazaFFM_2909 09.doc.

${ }^{34}$ See page 12 infra. 
possible, and must prioritize damaging assets over seeking out each and every launcher. Punishment must be aimed at decision makers and the power elite... In Lebanon, attacks should both aim at Hizbollah's military capabilities and should target economic interests and the centres of civilian power that support the organization. Moreover, the closer the relationship between Hezbollah and the Lebanese Government, the more the elements of the Lebanese State infrastructure should be targeted. Such a response will create a lasting memory among ... Lebanese decision makers, thereby increasing Israeli deterrence and reducing the likelihood of hostilities against Israel for an extended period. At the same time, it will force Syria, Hizbollah, and Lebanon to commit to lengthy and resource-intensive reconstruction programmes...

This approach is applicable to the Gaza Strip as well. There, the IDF will be required to strike hard at Hamas and to refrain from the cat and mouse games of searching for Qassam rocket launchers. The IDF should not be expected to stop the rocket and missile fire against the Israeli home front through attacks on the launchers themselves, but by means of imposing a ceasefire on the enemy.", 35

These polemic snippets - calculated to deter Hezbollah and Hamas from firing rockets at Israeli civilians - were selected from thousands of statements made over the years by IDF officers. Even so, not a single one of them - nor any statement quoted in the entire report - calls for the maximization of Palestinian civilian deaths, or for the specific targeting of Palestinian civilians. They specifically exclude targeting civilians for death from the list of appropriate punitive actions, such as damage to "national infrastructure," the "elimination of the Lebanese military" and generic "suffering of hundreds of thousands of people." Civilians always suffer from military actions, and even from lesser sanctions. For example, on December 11, 2009, U.S. Secretary of Defense Robert Gates warned that sanctions against Iran would be intended "to persuade the Iranian government that they would actually be less secure with nuclear weapons" because "their people will suffer enormously" from sanction. ${ }^{36}$ Surly such a statement could not be used to prove that the United States intends to kill Iranian civilians.

The so-called "Dahiya doctrine" of responding to rocket attacks with disproportionate force intended to destroy infrastructure says nothing about specifically targeting civilians for death. To the contrary, the quoted material says that "punishment must be aimed at the decision makers," referring to those who make the decision to allow the rockets to be fired, and to "civilian power that supports" the terrorist organization, namely Hamas. Ordinary people, civilians, are not mentioned. Their exclusion is significant. Yet the report misused this doctrine and these quotes to try to prove that the object of Operation Cast Lead was the killing of civilians.

\footnotetext{
${ }^{35}$ Goldstone Report $\mathbf{1} 1194-1197$.

${ }^{36}$ Glenn Kessler, Iran Probably a Target of Significant Sanctions, Gates Says, Boston GloBE, Dec. 12 , 2009, available at http:/www.boston.com/news/world/middleeast/articles/2009/12/12/ more_sanctions_ahead_for_iran_gates_says/.
} 
The report itself admits that it does not know "whether Israeli military officials were directly influenced by these writings.",37 But it reaches the conclusion that "what is prescribed as the best strategy appears to have been precisely what was put into practice." 38 Yes! The destruction of physical infrastructure. Not the targeting of civilians. Indeed, what was "put into practice" was a policy of warning civilians by phone, emails, leaflets and other means. As we shall see, Israel went to great lengths to protect civilians, not to attack them.

Instead of looking to the hard evidence that is completely inconsistent with any Israeli policy of targeting civilians and maximizing civilian deaths, the report focused on selective statements of Israeli leaders made before Operation Cast Lead and calculated to deter rocket attacks by threatening a disproportionate response.

It is more than ironic that the same report refused to credit much more specific statements made by Hamas leaders before Operation Cast Lead. On February 29, 2008, Fathi Hammad, a leading Hamas legislator, made the following statement:

"For the Palestinian people, death has become an industry, at which women excel, and so do all the people living on this land. The elderly excel at this, and so do the mujahideen and the children. This is why they have formed human shields of the women, the children, the elderly, and the mujahideen, in order to challenge the Zionist bombing machine. It is as if they were saying to the Zionist enemy: 'We desire death like you desire life.",39

The report quoted this statement and then chose to ignore it. This is what it said:

"Although the Mission finds this statement morally repugnant, it does not consider it to constitute evidence that Hamas forced Palestinian civilians to shield military objectives against attack."40

Nor apparently did it consider it in any way relevant to whether Palestinian civilians willingly allowed themselves to be used as human shields - or even as to whether the IDF might reasonably have believed it to be relevant when they planned the operation.

In contrast to this dismissive attitude toward this and other specific and bellicose statements ${ }^{41}$ and threats of Hamas political leaders, the report attributed considerable weight to vague and general statements made by Israeli political officials during and after Operation Cast Lead. It focused particularly on one statement made by Tzipi Livni who

\footnotetext{
${ }^{37}$ Goldstone Report 91199.

${ }_{38}^{38}$ Id. $\uparrow 1199$.

${ }^{39}$ Israel Ministry of Foreign Affairs, Hamas Exploitation of Civilians, Jan. 13, 2009, available at http://www.mfa.gov.il/MFA/Terrorism-+Obstacle+to+Peace/Terror+Groups/Hamas_Exploitation_ Civilians_Jan_2009.htm.

${ }^{40}$ Goldstone Report 9478.

${ }^{41}$ For instance, the report notes that a Hamas fighter said he tried to fire rockets and mortars near homes "in the hope that nearby civilians would deter Israel from responding." Goldstone Report $₫ 453$.
} 
was then Israel's Minister of Foreign Affairs. On January 13, 2009, Livni said, "We have proven to Hamas that we have changed the equation. Israel is not a country upon which you fire missiles and it does not respond. It is a country that when you fire on its citizens it responds by going wild — and this is a good thing." 42

The report also quotes Eli Yishai, then Minster of Industry, Trade and Labour. Yishai said on January 6, 2009, "It [should be] possible to destroy Gaza, so they will understand not to mess with us...it is a great opportunity to demolish thousands of houses of all the terrorists, so they will think twice before they launch rockets. I hope the operation will come to an end with great achievements and with the complete destruction of terrorism and Hamas. In my opinion, they should be razed to the ground, so thousands of houses, tunnels, and industries will be demolished....[T]he operation will continue until a total destruction of Hamas." 43 The report quotes Yishai as saying on February 2, 2009, "Even if the rockets fall in an open air or to the sea, we should hit their infrastructure, and destroy 100 homes for every rocket fired." 44

With these quotes in hand the report concludes, "Statements by political and military leaders prior to and during the military operations in Gaza leave little doubt that disproportionate destruction and violence against civilians were part of a deliberate policy." unlawful policy of disproportionate destruction of property. This argument is weak because the use of the word "disproportionate" quoted on page 9 supra does not constitute an admission that unlawfully disproportionate force would be employed under the standards of international law. Under international law, the harm collaterally inflicted on civilians must not be disproportionate to the military objective. ${ }^{46}$ But there is no prohibition against using overwhelming - that is disproportionate - military force against a legitimate military object. ${ }^{47}$ Israel had a perfect right to kill every single Hamas fighter, even if that number was in the thousands, in order to stop the rockets from endangering millions of Israeli civilians. The fact that 8,000 Hamas rockets succeeded in killing only a dozen or so Israelis, does not require Israel to limit the number of Hamas combatants killed. Reading the quote on page 8 does not suggest that the speaker was urging disproportionate civilian casualties but rather he was urging military force greater than and disproportionate to the number of Israelis killed by to the rockets that were being fired at Israeli civilians. This is perfectly lawful under international law. If proportionality were required in relation to military targets, it would be impossible for

\footnotetext{
${ }^{42}$ Goldstone Report $\uparrow 1206$.

${ }^{43}$ Id. $\uparrow 1204$.

${ }^{44}$ Id. ๆ 1205 (emphasis added).

${ }^{45} I d$. 1215 (emphasis added).

${ }^{46}$ See generally JEAN-MARIE HENCKAERTS \& LOUSE DosWALD-BeCK, CUSTOMARY INTERNATIONAL HUMANITARIAN LAW VOL. I, 46 ("Launching an attack which may be expected to cause incidental loss of civilian life, injury to civilians, damage to civilian objects, or a combination thereof, which would be excessive in relation to the concrete and direct military advantage anticipated, is prohibited.").

${ }^{47}$ See, e.g., JUdGe ADVOCATE GENERAL's SCHOOL, LAW OF WAR WORKSHOP DESKBOOK 166, available at $\mathrm{http} / / / \mathrm{www} . \mathrm{au} . \mathrm{af} . \mathrm{mil} / \mathrm{au} / \mathrm{awc} / \mathrm{awcgate} / \mathrm{law} / \mathrm{low}$-workbook.pdf (noting that the proportionality principle is "only applicable when an attack has the possibility of affecting civilians. If the target is purely military with no known civilian personnel or property in the vicinity, no proportionality analysis need be conducted.").
} 
countries like the United States to employ its overwhelming military weapons - drones, tomahawk missiles, stealth bombers - against terrorists, who are poorly equipped but determined to kill.

To argue, moreover, that these polemical statements directed against property and terrorists conclusively prove a "deliberate policy" of "violence against civilians" is simply absurd. Livni suggests that Israel will "go wild" on Hamas in order to restore deterrence, and nowhere suggests civilians will be targeted. Yishai says he wants to "destroy Gaza," but quickly clarifies that this means "complete destruction of terrorism and Hamas," a legitimate military objective. The report concludes that Yishai's quote regarding destruction of homes may suggest "reprisals against civilians ... contrary to international humanitarian law."48 Unsurprisingly, the report omits that in this same speech Yishai clarifies that homes destroyed will be "terrorists' homes while informing them in advance - so as not to hurt the family members." 49 This deliberate omission is particularly disturbing, since it is directly relevant to the report's most damning condemnation of Israel, and the omitted portion of the quote undercuts the report's conclusion. One can be extremely critical of some of the statements quoted in the report without using them as a basis for the non-sequitur argument that they prove an intent to do what they pointedly do not advocate: namely the deliberate killing of babies, innocent women and other civilians.

The report seems to realize its own weaknesses. It attempts to shore up the connection between political statements and a "deliberate policy" of "violence against civilians" by suggesting Israel sees Hamas' supporting infrastructure as "encompass[ing] effectively the population of Gaza." 50 According to this argument, Israel intentionally targets civilians because it considers them the Hamas infrastructure. The report's purported evidence for this dubious claim is the "indiscriminate and disproportionate impact of [Israel's] restrictions on the movement of goods and people [into Gaza]. "51 It simply does not follow, however, that Israel's blockade means Israel considers all Gaza civilians to constitute Hamas supporting infrastructure, or that all Gaza civilians are appropriate military targets. A blockade is a blunt instrument; by definition it is deleterious to civilian life (see, for instance, the statement by Robert Gates, quoted at page 9 supra). There is an enormous difference-a difference ignored by the report but not by Israelbetween depriving civilians of non-essential commodities and targeting civilians for murder. It is a classic non-sequitur to argue that a boycott proves an intent to kill.

The report's second piece of evidence that Israel considers all Gazans to be Hamas infrastructure is that Hamas won parliamentary elections. ${ }^{52}$ The Mission, of course, has no evidence that Israeli leadership considers Gazan civilians who voted for Hamas to constitute Hamas infrastructure. Moreover, many civilians did not vote in the election

\footnotetext{
${ }^{48}$ Goldstone Report 91216.

${ }^{49}$ Raanan Ben-Zur, Yishai: Destroy 100 Houses for Each Rocket Fired, YNET, Feb. 2, 2009, available at http://www.ynetnews.com/articles/0,7340,L-3665517,00.html.

${ }^{50}$ Goldstone Report $₫ 1211$.

${ }^{51} I d$. $\uparrow 1211$.

${ }^{52}$ Id. ๆ 1210 .
} 
and some who did voted against Hamas. The report stretches for any argument, no matter how unrealistic, to support its conclusion that Israel had a deliberate policy of murdering civilians.

In addition to relying on statements of military and political officials, the report also points to the IDF's advanced military capabilities in concluding that Israel intentionally targeted civilians. The argument is that, because the IDF uses such advanced weaponry, whenever civilians were killed, they must have been killed intentionally. On multiple occasions, the report notes that the IDF "possesses very advanced hardware" and that Israel is "a market leader in the production of some of the most advanced pieces of military technology available." ${ }^{53}$ It also notes that Israel has "very significant capacity for precision strikes" and "extensive and intimate knowledge" of Gaza. ${ }^{54}$ The report concludes that, "taking into account the ability to plan [and] the means to execute plans with the most developed technology available...the incident and patterns of events that are considered in this report have resulted from deliberate planning and policy decisions." 55

It should go without saying that, no matter how advanced or sophisticated weaponry may be, errors are made in the fog of war. A month before Operation Cast Lead, United States forces in Afghanistan attacked a wedding, killing nearly forty civilians. ${ }^{56}$ Although everyone agrees that the United States has advanced weaponry, no reasonable person would argue that this is proof that America was targeting an Afghan wedding party. Likewise, Israeli use of sophisticated weaponry should not serve as proof that Israelis intended to kill civilians during Operation Cast Lead. After all, the IDF killed several of its own soldiers through "friendly fire" mistakes. ${ }^{57}$

The Goldstone Report purports to connect advanced weaponry to intentional killing by erasing the possibility of error. The report paints the IDF as a military force that, unlike any other military force in the world, simply does not commit errors. The report quotes approvingly an IDF report stating that "99 per cent of the [air force] firing that was carried out hit targets accurately." 58 There are two problems with relying on this figure to conclude intentionality. First, the figure speaks only to the air force and does not include ground force accuracy. The air force, with its guided weapons, more often hits intended targets than, for instance, a tank attempting to shell its attackers. The overall IDF accuracy rate must be lower than $99 \%$. The second issue with concluding intentionality from an accuracy figure is the mistake of fact issue. If an Israeli soldier targets a person he believes to be a militant and kills him, but the person killed was not a militant, the soldier still made 'accurate' use of his weapon within the meaning of the $99 \%$ figure. However, because the soldier made a mistake of fact, he would not possess the requisite purpose to be liable for intentional killing of a civilian. This is particularly significant in

${ }^{53} I d .961$.

${ }_{55}^{54}$ Id. १甲 $1185,1180$.

${ }^{55} I d$. $\uparrow 1190$.

${ }^{56}$ Tom Coghlan, US Says Sorry After Wedding Party is Bombed in Ambush, THE TIMES (London), Nov. 6, 2008.

${ }_{58}^{57}$ Goldstone Report 9364.

${ }^{58}$ Id. $\uparrow 1188$. 
light of the fact that so many Hamas combatants wore civilian clothing and mingled with the civilian population.

In one of the incidents the report investigated, the attack on the al-Daia residence, Israel claimed a mistake of fact defense. According to Israel, "[T]he IDF intended to strike a weapons' storage facility located in a building next this [the Al-Daia] residence.

However, the IDF erroneously targeted the Al-Daia residence, rather than the weapons storehouse." 59

The report claims that it is aware of no other Israeli admissions of error besides the AlDaia incident. Therefore, the report makes the astonishing conclusion that no other errors occurred. The report reads, "[S]ince it [the Al-Daia incident] appears to be the only incident that has elicited admission of error by the Israeli authorities, the Mission takes the view that the Government of Israel does not consider the other strikes brought to its attention to be the result of similar or other errors." ${ }^{~} 60$ It is important to note the implication that this statement concerns all incidents, not just those incidents investigated in the report. After all, the statement is made in a section discussing "the objectives and the strategy underlying the Israeli military operations in Gaza." The Mission's claim, however, that "it has found only one example [Al-Daia] where the Israeli authorities have acknowledged that an error had occurred," 61 is not made in good faith. Justice Goldstone and the Mission need only look at the Israeli government report entitled "The Operation in Gaza" (cited over 50 times in the Goldstone Report) to find other Israeli admissions of error. In "The Operation in Gaza," the Israeli government claims that an attack on an oxygen truck that killed four civilians and four Hamas militants was a mistake of fact error. The IDF erroneously believed the oxygen canisters to be rockets and targeted the truck for destruction. ${ }^{62}$ Four out of the nine IDF deaths were caused by friendly fire. ${ }^{63}$ Of course these deaths were errors. Surely there were many more errors, as there always are in war. ${ }^{64}$ To assume that all of the deaths caused by errors were, in fact, deliberate, begs the critical question and reflects the bias of the report.

The fourth category of evidence the Goldstone Report relies upon in concluding Israel had a policy of murdering civilians is simply the number of civilian casualties. At the outset it must be noted that the death of civilians does not automatically prove commission of war crimes. According to Louis Moreno-Ocampo, Chief Prosecutor of the International Criminal Court, "Under international humanitarian law and the Rome Statute, the death of civilians during an armed conflict, no matter how grave and regrettable, does not in itself constitute a war crime. International humanitarian law and the Rome Statute permit belligerents to carry out proportionate attacks against military

\footnotetext{
${ }^{59} I d$. 9854 . The report is skeptical of this defense, and claims the Israeli explanation "appears to lack coherence and raises more questions than it answers." $I d$. $\mid 860$.

${ }^{60} \mathrm{Id}$. 1187.

${ }^{61} I d .91187$.

${ }^{62}$ State Of IsRael, The OPERATION In GaZa: Factual AND Legal Aspects $9 \uparrow$ 398-400 (July 2009), available at http://www.mfa.gov.il/NR/rdonlyres/E89E699D-A435-491B-B2D0017675DAFEF7/0/ GazaOperationwLinks.pdf [hereinafter THE OPERATION IN GAZA: FACTUAL AND LEGAL ASPECTS]. 
objectives, even when it is known that some civilian deaths or injuries will occur."65 The report strongly implies that the number of civilians killed in Operation Cast Lead is evidence of Israel's intent to kill civilians. Results prove intent, at least when it comes to Israel. ${ }^{66}$ For instance, the report notes that "some of those killed were combatants directly engaged in hostilities against Israel, but many were not. The outcome and the modalities of the operations indicate, in the Mission's view, that they were only partially aimed at killing leaders and members of Hamas, al-Qassam Brigades and other armed groups." ${ }^{\circ 7}$ But a careful analysis of the results, in fact, proves the exact opposite.

The chart below illustrates a breakdown of Palestinian casualties during the Gaza operation as reported by the Palestinian Centre for Human Rights, B'Tselem, and the Israeli Defense Forces. The PCHR maintains that 1,417 people were killed by Israeli forces, including 926 civilians, 255 policemen, and 236 combatants. B'Tselem counts 1,387 Palestinian deaths, including 773 civilians, 248 policemen, 330 combatants, and 26 unknown. ${ }^{68}$ The IDF claim the total number of casualties was 1,166, including 295 civilians, 709 combatants (the IDF includes policemen in the combatant category) and 162 unknown.

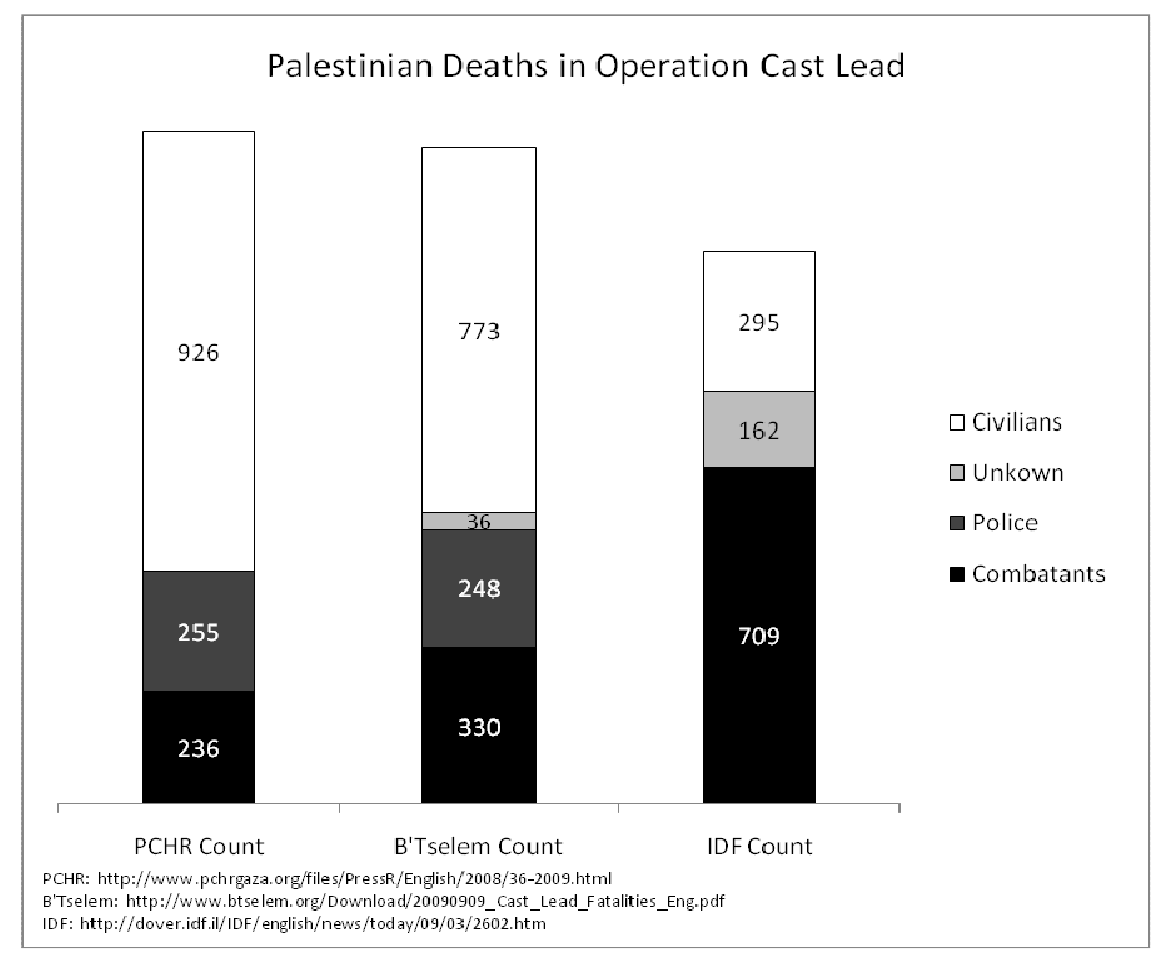

\footnotetext{
${ }^{65}$ Letter from Louis Moreno-Ocampo, Chief Prosecutor of the International Criminal Court (Feb. 9, 2006), available at http://www2.icc-cpi.int/NR/rdonlyres/F596D08D-D810-43A2-99BBB899B9C5BCD2/277422/OTP_letter_to_senders_re_Iraq_9_February_2006.pdf.

${ }^{66}$ Contrast this approach with that taken with regard to "results" attributable to Hamas, such as the wearing of civilian clothing, which the report deems to be without significance to the intentions of Hamas.

${ }^{67}$ Goldstone Report $₫ 1890$.

${ }^{68} \mathrm{~B}$ 'Tselem has revised its casualty count slightly and now counts 762 civilian deaths. The new figures do break down the casualties into categories of unknown/ civilians/ police/ combatants, so the older figures are used here. See B'Tselem, One Year Since Operation Cast Lead, Still No Accountability, Dec. 27, 2009, available at http://www.btselem.org/English/Gaza_Strip/20091227_A_year_to_Castlead_Operation.asp.
} 
To deconstruct these figures properly, the status of the Gaza police must first be considered, since approximately 250 of them were among those listed as "civilians" who were killed. Although the Goldstone Report concludes that the Gaza police force was a "civilian law-enforcement agency," 69 there is overwhelming evidence to suggest otherwise. The Gaza police has its origins in the Hamas Executive Force. When the Executive Force was formed in 2006, its commander announced that the force was "the nucleus of the future Palestinian army. The resistance must continue. We have only one enemy. They are Jews. We have no other enemy. I will continue to carry the rifle and pull the trigger whenever required to defend my people." 70 According to the report, the Executive Force merged with a reorganized PA police in October 2007. ${ }^{71}$ Despite the fact that the Executive Force no longer technically exists, during Operation Cast Lead a police spokesman said, "Police officers received clear orders from the leadership to face the enemy, if the Gaza Strip were to be invaded.",72 This is conclusive evidence that the Gaza police were not entitled to the protections accorded to civilians in war. In addition, evidence suggests many policemen were combatant individuals regardless of their connection with the police. ${ }^{73}$ According to one count, $91 \%$ of the policemen killed were either members of a terrorist organization or in infantry training, with a "decisive majority" of casualties belonging to military wings. ${ }^{74}$ In any event, reasonable people can and do disagree as to the status of the Gaza policemen killed by Israel. They cannot simply be lumped together with infants and other obvious non-combatants for purposes of listing the number of dead civilians. ${ }^{75}$

There is clearly a large divergence between the IDF numbers and the PCHR and B'Tselem numbers. Although the Goldstone report claims that Israel's numbers "fall far short of international law standards,"76 the PCHR numbers that the report cites are

\footnotetext{
${ }^{69}$ Goldstone Report. 4336.

${ }^{70}$ Id. I 412; New PA Police Chief Marks Jews as “Only Enemy” of Palestinians, HaARETZ, Apr. 23, 2006, available at http://www.haaretz.com/hasen/pages/ShArt.jhtml?itemNo=708275\& contrassID $=1 \&$ subContrassID $=0 \&$ sbSubContrassID $=0$. The Goldstone Report omitted "They are Jews. We have no other enemy," which is present in the original quote.

${ }^{71}$ Goldstone Report $₫ 414$.

${ }^{72} I d$. 9416.

${ }^{73}$ See INTERNATIONAL INSTITUTE FOR COUNTER-TERRORISM, INTERDISCIPLINARY CENTER HERZLIYA, CASUAlties IN OPERATION CAST LEAD: A ClOSER LOOK 9 (2009), available at http://www.ict.org.il/Portals/0/Articles/ICT_Cast_Lead_Casualties-A_Closer_Look.pdf [hereinafter CASualties in Operation CASt Lead: A CLoser LoOK].

${ }^{74}$ Jonathan D. Halevi, Jerusalem Centre for Public Affairs, Palestinian Policemen Killed in Gaza Operation Were Trained Terrorists, Sept. 13, 2009, available at http:/www.jcpa.org/JCPA/Templates/ShowPage.asp?DRIT=1\&DBID=1\&LNGID=1\&TMID=111\&FID=4 $42 \& \mathrm{PID}=0 \& \mathrm{IID}=3081 \& \mathrm{TTL}=$ Palestinian_\%E2\%80\%9CPolicemen $\% \mathrm{E} 2 \% 80 \% 9 \mathrm{D}$ Killed_in_Gaza_Operat ion_Were_Trained_Terrorists. The Mission dismisses this evidence as unreliable on the basis that some policemen were characterized as members of the al-Qassam Brigades simply because they were Hamas members and because terrorist groups are known to 'adopt' civilians as martyrs on their websites. See Goldstone Report 9 422-423. While the sources cited here do rely to a degree on terrorist websites, and it is possible that some civilians were 'adopted' as martyrs, Israel is entitled to take the statements of Hamas at face value. Hamas simply cannot have it both ways, claiming that someone is a civilian at one point, and then claiming that he is a combatant after he dies. Not only is this hypocritical, but it shows great disrespect for the internationally recognized principal of distinction.

${ }^{75}$ See discussion of continuum of civilianality at page 27 infra.

${ }^{76}$ Goldstone Report $₫ 361$.
} 
considerably more troubling. For instance, some Palestinian casualties that were counted by PCHR as civilians were undoubtedly combatants. PCHR classified Abdullah Abdul Hamid Hussam Abu Mu'ammar, Mohammed Akram Mohammed Abu Harbid, and Belal Hamza Ali 'Ubeid (under 18) as civilians and identified all three as students. ${ }^{77}$ Here are pictures of these three "civilians" from a militant website. ${ }^{78}$
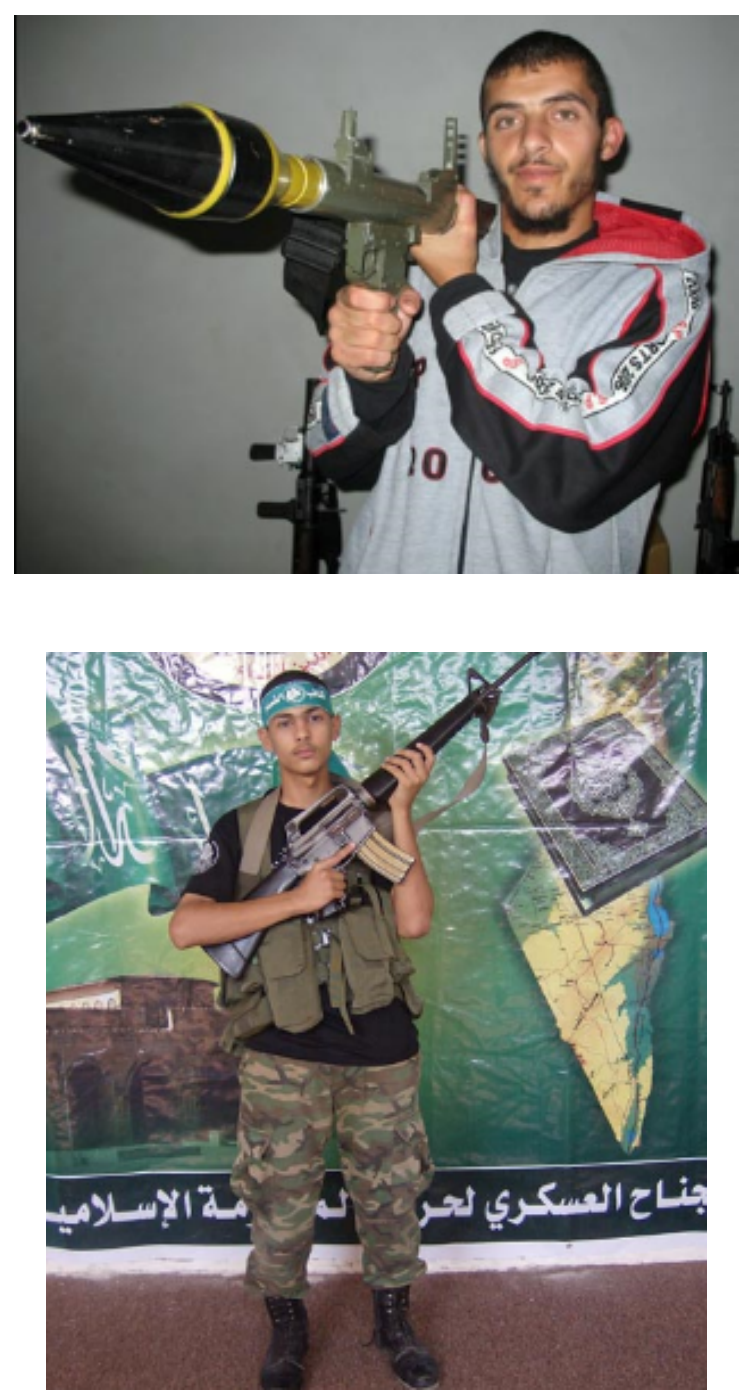

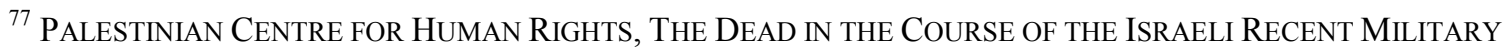
OFFENSIVE ON THE GAZA STRIP, available at http://www.pchrgaza.org/files/PressR/English/2008/list.pdf. Regarding the issue of 'adoption' see note 74 supra.

${ }^{78} \mathrm{http}: / / \mathrm{www}$.alqassam.ps/arabic/sohdaa5.php?sub_action=picture\&id=1305; http://www.alqassam.ps/arabic/sohdaa5.php?sub_action=picture\&id=1301;

http://www.alqassam.ps/arabic/sohdaa5.php?sub_action=picture\&id=1439. For more examples of militants characterized as civilians on PCHR's list, see Cast Lead - New Species of Militants - Civilians, available at http://www.hosem.org.il/Cast-Lead.
} 


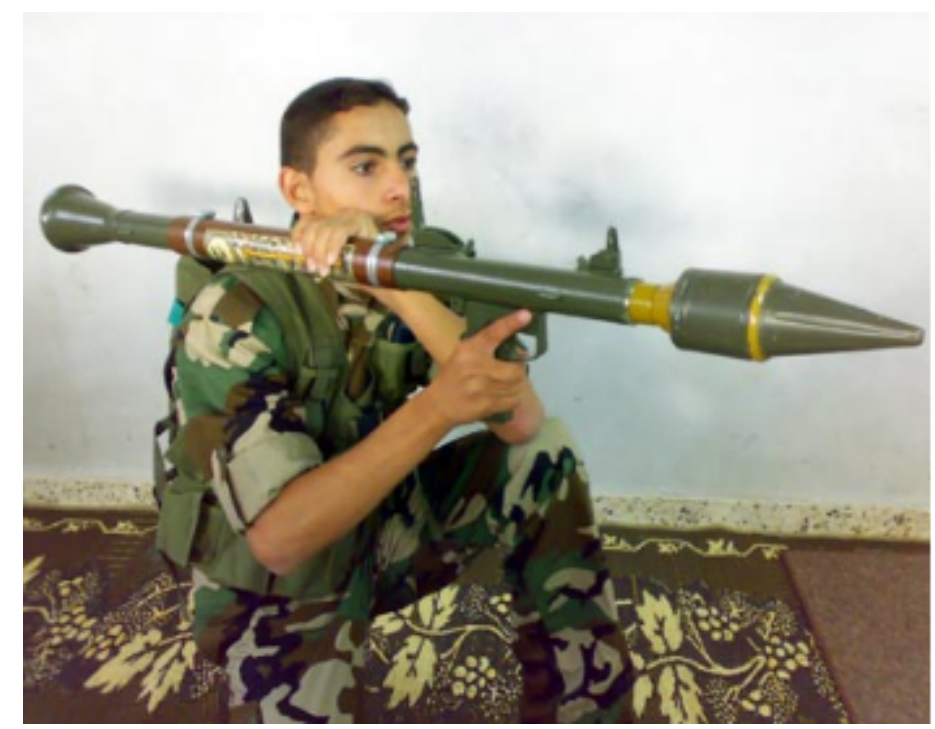

The second problem with the PCHR numbers is a statistical discrepancy that cannot be squared with the Goldstone Report's conclusion that Israel intentionally and indiscriminately targeted civilians. The International Institute for Counter-Terrorism (ICT) at the Interdisciplinary Center Herzilya independently determined from PCHR's casualty list 314 combatants, 239 policemen, and 363 civilians. This left 518 people with an unknown status. If Israel killed civilians intentionally and indiscriminately, we should expect the distribution within the civilian/unknown category to be proportionate to the Gaza population, roughly $25 \%$ men, $25 \%$ boys, $25 \%$ girls, $25 \%$ women. ${ }^{79}$ Instead, ICT found the civilian/unknown category was composed of $56 \%$ men, $22 \%$ boys, and $22 \%$ girls and women combined. ("Boys" and "girls" are defined as under $18,{ }^{80}$ and many boys and girls in Gaza are combatants by any definition of that term. Indeed 16 and 17 year olds are often used in martyr operations, precisely because of their youthful appearance.) These statistics are relevant for two reasons. First, the demographic (men) that is more likely to actually be terrorists, is vastly over-represented in the unknown/civilian category. Second, the demographic (men) that Israel is more likely to mistake as terrorists is vastly over-represented in the unknown/civilian category. In any case, these statistics are completely inconsistent with claims of intentional, indiscriminate killing of civilians. ${ }^{82}$

Despite the problematic nature of the highly-biased PCHR count, even the story the raw PCHR numbers tell are not evidence of intent to kill civilians. If we count policemen as combatants, there were according to PCHR 491 combatant deaths and 926 civilian deaths. Thus, even according to one of the most biased and skewed sources available, there was a combatant casualty to civilian casualty ratio of 1 to 1.885 . That is, for every

\footnotetext{
${ }^{79}$ Gaza has a young median age. See CASualties in Operation Cast LeAD: A Closer LoOK 11.

${ }^{80} \mathrm{Id}$. 10. It is true that males, whether terrorists or not, are more likely to be out and about, and thus in harm's way, than females, especially in a traditional society, but if Israel had a policy of indiscriminately targeting civilians, including in their homes - as the report suggests - this factor would be negligible. ${ }^{82}$ See Id. 12.
} 
Palestinian combatant killed, less than two civilians were killed. It is sad that so many innocents died during the Gaza war, but numbers alone do not prove that Israel intended to kill civilians, especially in light of how Hamas used civilians as shields (see section III infra). A United Nations report estimates that worldwide $75 \%$ of war casualties are civilians. ${ }^{83}$ Some have suggested that the combatant-civilian casualty ratio for America's recent drone attacks in Pakistan is as high as 1 to $10 .{ }^{84}$ Others have suggested that during NATO's 1999 Kosovo operation, there were four civilian casualties for every combatant casualty. ${ }^{85}$ In late December of 2009, an American air strike killed ten civilians in Afghanistan. ${ }^{86}$ Although there are valid arguments about the prudence of these operations, no reasonable person argues that these numbers prove an intention to kill Pakistani, Yugoslav, or Afghani civilians.

If the ratio alone proves anything it is that there was a policy of reducing civilian deaths, not targeting civilians. If Israel's intention was truly to kill civilians, why was the combatant to civilian casualty ratio only one to less than two? Certainly if one of the world's most advanced military forces intended to kill civilians it could have made that ratio one to five or even one to ten. As Professor Halbertal writes, "There are 1.5 million people in Gaza and around 10,000 Hamas militants, so the ratio of militants to civilians is 1:150. If Israel targeted civilians intentionally, how on earth did it reduce such a ratio to $1: 3$ or $2: 3 ? " 87$

The report's final argument, made implicitly at various points in the document, goes something like this: Israel deliberately targeted non-human civilian targets, such as a flour mill and a wastewater plant; this proves that the IDF wanted to punish civilians who relied on these facilities; it follows therefore that the IDF deliberately intended to hit human civilian targets and kill as many civilians as possible. There are two responses to this argument, the first factual, the second logical.

As to the facts, the New York Times has reported that the IDF study, soon to be released, will dispute the claim that Israel willfully targeted the food and wastewater plant:

"The Goldstone report asserts that the Bader flour mill 'was hit by an airstrike, possibly by an F-16.' The Israeli investigators say they have photographic proof

\footnotetext{
${ }^{83}$ The Secretary-General, Report of the Secretary-General to the Security Council on the Protection of Civilians in Armed Conflict, $\{3$, U.N. Doc. S/2001/331 (Mar. 30, 2001). This statistic includes both internal wars and wars in which civilians are the object of attack. It is also worth noting that many conflicts produce many more casualties yet receive much less media attention. Over the last twenty years, there have been 10,000 total casualties in the Arab-Israeli conflict. In same time period the hostilities in the Democratic Republic of the Congo have killed millions. Goldstone's Gaza Report: Part II.

${ }^{84}$ Daniel L. Byman, Do Targeted Killings Work?, ForeignPOLICY.COM, July 14, 2009, available at http://www.foreignpolicy.com/articles/2009/07/14/do_targeted_killings_work?page=full.

${ }^{85}$ Michael Oren, UN Report a Victory for Terror, BOSTON GLOBE, Sept. 24, 2009, available at http://www.boston.com/bostonglobe/editorial_opinion/oped/articles/2009/09/24/un_report_a_victory_for_t error/.

${ }^{86}$ Laura King, US Forces Reportedly Kill 10 Afghan Civilians, Boston GloBe, Dec. 29, 2009, available at http://www.boston.com/news/world/asia/articles/2009/12/29/us_airstrike_reportedly_kills_10_afghan_civil ians/.

${ }^{87}$ The Goldstone Illusion.
} 
that this is false, that the mill was accidentally hit by artillery in the course of a firefight with Hamas militiamen. The dispute is significant since the United Nations report asserts that 'the destruction of the mill was carried out for the purpose of denying sustenance to the civilian population,' an explicit war crime. A second finding concerned the destruction of a wastewater plant, leading to an enormous outflow of raw sewage. The Goldstone report contended that it was hit by a powerful Israeli missile in a strike that was 'deliberate and premeditated.' The Israelis say they had nothing to do with that plant's collapse and suggest that it may have been the result of Hamas explosives." 88

I will have more to say about these incidents following the release of the Israeli rebuttal. But even if it were true that Israel sought to punish the civilian population of Gaza by attacking food and sewage facilities, it would not follow that Israel intended to kill civilians. Israel acknowledged that it deliberately limits the flow of consumer goods into Gaza as part of an effort to impose sanctions on the Hamas government for its policy of targeting Israeli civilians with anti-personnel weapons. Just as American sanctions against Iran would cause the Iranian "people [to] suffer," 89 so too to do Israeli sanctions. But it is a far cry from sanctions to murder, and it is a non-sequitur to argue that the destructions of non-human civilian targets proves an intention to target human beings for death.

Nowhere does the report detail how difficult it is, in the fog of war, to target combatants while avoiding civilian casualties. Nowhere does the report detail the great lengths Israel goes to in order to spare civilian lives. It does not give any historical context. It does not mention how, under the leadership of air force chief Eliezer Shkedi, the IDF worked diligently to decrease the combatant-civilian air attack casualty ratio from 1 to 1 during the second intifada in 2003 to an astounding one civilian for every thirty combatants in $2007 .^{90}$ This is the best ratio ever achieved by an armed force, and it required enormous dedication of resources and commitment to reduce civilian casualties, even those closely related to terrorist leaders. Nor does Goldstone mention that routine Israeli policy sacrifices valuable military opportunities in order to protect innocent civilians. The report does not tell the reader that, when Israel targeted a high-level Hamas meeting in 2003 , it used a relatively light bomb in order to avoid civilian casualties. Since it did not attack its targets with full capacity, all of the militants (including the Hamas leader) escaped. ${ }^{91}$

The report does not even discuss Israel's professed operating procedures during Operation Cast Lead. It does not discuss how the humanitarian impact on a target was

\footnotetext{
${ }^{88}$ Ethan Bronner, Israel Poised to Challenge a U.N. Report on Gaza, New YoRK TIMES, Jan. 23, 2010, available at http://www.nytimes.com/2010/01/24/world/middleeast/24goldstone.html.

${ }^{89}$ See statement of U.S. Secretary of Defense Robert Gates, page 10 supra.

${ }^{90}$ Amos Harel, Pinpoint Attacks on Gaza More Precise, HAARETZ, Dec. 30, 2007, available at http://www.haaretz.com/hasen/spages/939517.html.

${ }_{91}$ Amos Harel \& Arnon Regular, Hamas's Yassin Survives Gaza Strike, HAARETZ, available at http://www.haaretz.com/hasen/pages/ShArt.jhtml?itemNo=337342\&contrassID=2\&subContrassID=1\&sbS ubContrassID=0\&listSrc $=Y$; Molly Moore \& John Ward Anderson, Israeli Jet Bombs Hamas Meeting, Injuring Spiritual Leader, WASHINGTON POST, Sept. 7, 2003, available via Lexis.
} 
considered both at the planning stage and immediately prior to attack. ${ }^{92}$ It does not inform the reader that where an air force pilot saw civilians straying into the path of an already-launched missile, where possible, he diverted the missile to avoid excess civilian casualties. ${ }^{93}$ The Goldstone Report does not mention that under IDF operating procedure, moving targets are to be struck when they are as far away from civilians as possible. ${ }^{94}$ During the latter part of Operation Cast Lead the IDF, to its great detriment, "unilaterally suspended military operations for at least three hours each day, to enable re-supply of the population and other humanitarian relief activities." 95 The IDF deployed 120

humanitarian support officers during the operation. ${ }^{96}$ How is any of this consistent with a general policy of targeting civilians?

Israel's efforts to protect civilians who were placed in harm's way by Hamas' decision to fire rockets from densely populated urban areas was unprecedented in military history. The Goldstone Mission deliberately chose to ignore the best expert testimony on precisely this issue. Here is what the former commander of British forces in Afghanistan, Colonel Richard Kemp, told the United Nations Human Rights Council on October 16, 2009:

"I am the former commander of the British forces in Afghanistan. I served with NATO and the United Nations; commanded troops in Northern Ireland, Bosnia and Macedonia; and participated in the Gulf War. I spent considerable time in Iraq since the 2003 invasion, and worked on international terrorism for the UK Government's Joint Intelligence Committee.

Mr. President, based on my knowledge and experience, I can say this: During Operation Cast Lead, the Israeli Defence Forces did more to safeguard the rights of civilians in a combat zone than any other army in the history of warfare.

Israel did so while facing an enemy that deliberately positioned its military capability behind the human shield of the civilian population.

Hamas, like Hizballah, are expert at driving the media agenda. Both will always have people ready to give interviews condemning Israeli forces for war crimes. They are adept at staging and distorting incidents.

The IDF faces a challenge that we British do not have to face to the same extent. It is the automatic, Pavlovian presumption by many in the international media, and international human rights groups, that the IDF are in the wrong, that they are

\footnotetext{
92 The Operation In GAZA: FACTUAL AND LEGAL AsPeCts $\uparrow \uparrow$ 251-252.

${ }^{93}$ Id. $9 \uparrow 252,255$. See also IDF Spokesperson's Unit, IDF Vlog: Israeli Airstrikes Aborted to Protect Civilians, Jan. 14, 2009, available at http://idfspokesperson.com/2009/01/14/idf-vlog-israeli-airstrikes-aborted-to-protect-civilians/.

94 THE OPERATION IN GAZA: FACTUAL AND LEGAL ASPECTS $₫ 258$.

${ }^{95} \mathrm{Id}$. 9276 . This is despite the fact that "[h]ostilities are seldom fully or partly suspended in order to permit humanitarian action." Toni Pfanner, Asymmetrical Warfare from the Perspective of Humanitarian Law and Humanitarian Action, 87 INT'L REV. RED CROSS 149, 168.

96 THE OPERATION IN GAZA: FACTUAL AND LEGAL ASPECTS $₫ 269$.
} 
abusing human rights.

The truth is that the IDF took extraordinary measures to give Gaza civilians notice of targeted areas, dropping over 2 million leaflets, and making over 100,000 phone calls. Many missions that could have taken out Hamas military capability were aborted to prevent civilian casualties. During the conflict, the IDF allowed huge amounts of humanitarian aid into Gaza. To deliver aid virtually into your enemy's hands is, to the military tactician, normally quite unthinkable. But the IDF took on those risks.

Despite all of this, of course innocent civilians were killed. War is chaos and full of mistakes. There have been mistakes by the British, American and other forces in Afghanistan and in Iraq, many of which can be put down to human error. But mistakes are not war crimes.

More than anything, the civilian casualties were a consequence of Hamas' way of fighting. Hamas deliberately tried to sacrifice their own civilians.

Mr. President, Israel had no choice apart from defending its people, to stop Hamas from attacking them with rockets.

And I say this again: the IDF did more to safeguard the rights of civilians in a combat zone than any other army in the history of warfare." 97

Colonel Kemp had made the same points during Operation Cast Lead and they were well known to the writers of the Goldstone Report, who deliberately chose to ignore this expert testimony. Goldstone acknowledged that the omission was deliberate and tried to explain it away:

"[T] was no reliance on Col. Kemp mainly because in our Report we did not deal with the issues he raised regarding the problems of conducting military operations in civilian areas and second-guessing decisions made by soldiers and their commanding officers 'in the fog of war." "98

That is a willful lie. The report dealt specifically with precisely that issue. Everything the Israeli Army did was done in the course of a difficult military operation designed to stop rockets fired from civilian areas from targeting a million Israeli children, women and other civilians. The basic flaw of the Goldstone Report is that, without a scintilla of evidence, the biased commissioners concluded that the Israeli military action in Gaza was motivated not by the defense of its citizens but rather by desire to murder Palestinian civilians. Based on that unproven, untrue and biased conclusion, the commission was

\footnotetext{
${ }^{97}$ Richard Kemp, Remarks at Emergency Session of the U.N. Human Rights Council (Oct. 16, 2009), available at http://www.unwatch.org/site/apps/nlnet/content2.aspx? $\mathrm{c}=\mathrm{bdKKISNqEmG \& b=1313923 \& ct=}$ 7536409.

${ }^{98}$ E-mail from Richard Goldstone to Maurice Ostroff (Sept. 21, 2009, 22:34), available at http://mauriceostroff.tripod.com/id233.html.
} 
then able to ignore massive evidence, much of it self-proving and easily available on the internet, that the Israeli Army took considerable steps to reduce civilian casualties, while engaged in military action designed to prevent the murder of its own civilians. Had it considered and credited Colonel Kemp's conclusion that "the IDF did more to safeguard the rights of civilians in a combat zone than any other army in the history of warfare," it could not come to the mendacious conclusion it reached, namely that it was the explicit policy of the IDF to target Palestinian civilians and to maximize civilian deaths. A nation's armed forces cannot at the same time do more to safeguard civilians than any army in history, while it is targeting them for death. There is a simpler and more sinister reason why the report chose to ignore the expert testimony of Colonel Kemp: it totally undercut the central conclusion of the report regarding Israel's policy, intentions and actions. The very idea that the report "did not deal with the issues" raised so powerfully by Colonel Kemp, as Goldstone has claimed, speaks volumes about the bias of its authors.

For the most part, the report dismisses Israeli attempts to aid civilians. As Professor Moshe Halbertal wrote:

"In line with [the] principles [developed for the IDF by Professor Halbertal and others], the Israeli Air Force developed the following tactic. Since Hamas hides its headquarters and ammunition storage facilities inside civilian residential areas, the Israeli army calls the residents' telephones or cell phones, asking them to move immediately out of the house because an attack is imminent. But Hamas, in reaction to such calls, brings the innocent residents up to the roof, so as to protect the target from an attack, knowing that, as a rule, the Israeli army films the target with an unmanned drone and will avoid attacking the civilians on the roof. In response to this tactic, Israel developed a missile that hits the roof without causing any actual harm in order to show the seriousness of its intention. The procedure, called 'roof-knocking,' causes the civilians to move away before the deadly attack."

"It is rather a strange point in the Goldstone Report that this practice, which goes a long way to protect civilians, is actually criticized. Concerning such a practice, the report states that, "if this was meant as a warning shot, it has to be deemed reckless in the extreme." The truth is that this is an admirable and costly effort to avoid civilian collateral harm. As is true with many of its criticisms, the report does not state what the alternative should be. What should Israel do in such a case? Attack the house without calling on its residents to move, or attack it while they are gathered on the roof? Or maybe avoid attacks altogether, allowing the enemy to take effective shelter among civilians?"99

Neither the report nor its author addressed Professor Halbertal's questions.

\footnotetext{
${ }^{99}$ The Goldstone Illusion.
} 
It also ignored the vast evidence of Israeli actions on the ground that were utterly inconsistent with any purported policy of targeting civilians or maximizing civilian deaths. These actions included the evacuation to Israeli hospitals of wounded civilians, ${ }^{100}$ the foregoing of appropriate military targets because the risk to civilians was too great, ${ }^{101}$ and - as Colonel Kemp explained - the massive repeated and expensive warnings the IDF provided to civilians. Finally, the report virtually ignores the fact that Israel choose not to invade Gaza City. Only this phase would have assured military victory by capturing or killing the Hamas fighters responsible for the planning and firing of rockets. ${ }^{102}$ At least part of the reason for not invading Gaza City was the realization that many Palestinian civilians would inevitably be killed or injured. Here is a picture of Israel admitting a Gazan child for treatment through the Erez Crossing on Dec. 31, 2008. ${ }^{103}$

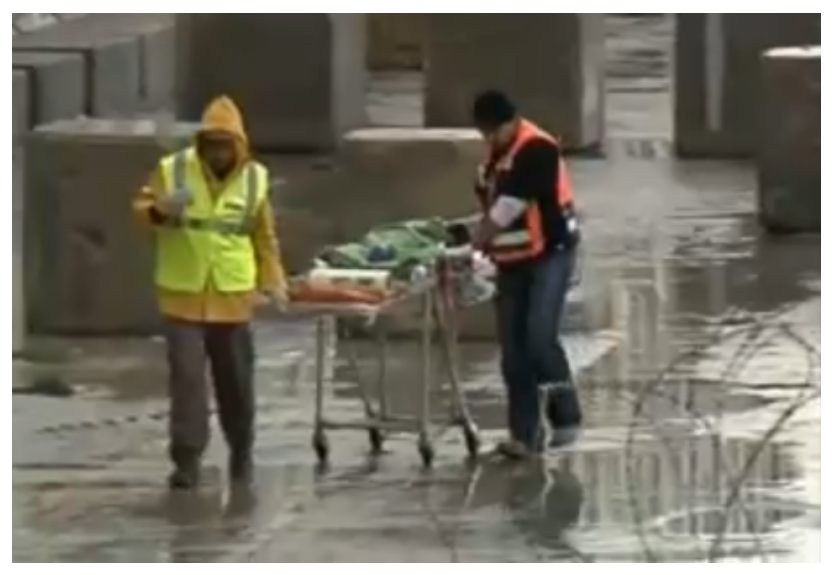

As the New York Times recently reported:

"General Halamish said in an interview that the army chose not to attack many leaders of Hamas because they lived among children and the elderly. He added that during the operation, Israel withheld fire for three hours a day so food and other aid supplies could be brought into Gaza. During these hours he said, a quarter of the shooting from Hamas took place. Hamas also ambushed the civilian supply trucks."

"Another senior military official who spoke on the condition of anonymity following regular military practice, said that neither the military command structure nor the government wanted to invade Gaza in December 2008, but felt

\footnotetext{
${ }^{100}$ See, e.g., Fadi Eyadat \& Dana Viler-Pollak, 12 Palestinians Hurt in Gaza Fighting Being Treated in Israeli Hospitals, HAARETZ, Jan. 1, 2009, available at http://www.haaretz.com/hasen/spages/1051946.html. ${ }^{101}$ See, e.g., THE OPERATION IN GAZA: FaCtUAL AND LEGAL ASPECTS $\uparrow 155$.

${ }^{102}$ See, e.g., Larry Derfner, The Obama Factor in Israel's Gaza War, U.S. NEWs \& WORLD REPORT, Jan. 14, 2009, available via Lexis.

${ }^{103}$ IDF Spokesperson's Unit, Gazan Child Taken to Israel for Treatment, posted Dec. 31, 2008, available at http://idfspokesperson.com/2008/12/31/gazan-child-taken-to-israel-for-treatement/.
} 
that the continental rocket attacks by Hamas on Israeli civilians forced their hand. The war, he said, followed the least aggressive of three contemplated routes conquer Gaza and occupy it again as was done in the West Bank in 2002, retake Hamas's weapons supply routes and hold them to dry out the organization's arsenal, or attack the Hamas military and state infrastructure and leave. It was the third that occurred." 104

The report does not address these facts on the ground. Nor does it consider the most basic question of all: What would Israel gain by targeting civilians for death? It simply is not rational for Israel to target civilians. The Goldstone Report has brought worldwide condemnation upon Israel. Surely Israel would not want to bring such condemnation upon herself.

Every Israeli official understands that every time a Palestinian civilian — especially a child or woman - is killed, Israel loses. As a western diplomat put it several years ago: Palestinian terrorists have "mastered" the "harsh arithmetic of pain." "Palestinian [civilian] casualties play in their favor, and Israeli [civilian] casualties play in their favor." 105 Every time a Palestinian terrorist kills an Israeli civilian, Hamas wins. And every time an Israeli soldier kills a Palestinian civilian, Hamas wins. That is their strategy, and it is a win-win for terrorism and a lose-lose for democracy. ${ }^{106}$ Civilian deaths are inevitable in a conflict of this kind, but the accusation that they are part of a deliberate Israeli plan or policy defies reality and is wrong as a matter of fact. Reasonable people may disagree as to whether the deaths that resulted from Israel's military objects were proportional or disproportional to risks its civilians feared from Hamas rockets. Reasonable people could also disagree about whether Israel's policy of destroying Hamas buildings, tunnels and industry should be permissible under international law. But that is not the essence of what the report accuses Israel of deliberately planning - namely the deliberate targeting and killing of hundreds of innocent Palestinian women and children. On this most serious of charges, not only is there absolutely no evidence that points to this conclusion, what evidence there is points exactly the other way. Yet the report distorts the evidence, misquotes its sources, and turns the truth on its head, in order to arrive at a conclusion that at least some of its members had reached before even beginning to gather evidence for the report.

It is important to note that the report contains disturbing narratives accusing IDF soldiers of murdering Palestinian civilians. The Goldstone Report does not contain enough evidence to prove war crimes were committed, but parts of it do suggest investigations should be opened into the conduct of certain soldiers. Israel fully accepts the obligation to investigate and has carried out investigations of 140 incidents. ${ }^{107}$ If any soldiers committed war crimes, they should be prosecuted and punished in accordance with Israeli

\footnotetext{
${ }^{104}$ Ethan Bronner, Israel Poised to Challenge a U.N. Report on Gaza, NEW YoRK TIMES, Jan. 23, 2010, available at http://www.nytimes.com/2010/01/24/world/middleeast/24goldstone.html.

${ }^{105}$ James Bennet, Arafat's Edge: Violence and Time on His Side, NeW York Times, Mar. 18, 2002.

${ }^{106}$ See Alan Dershowitz, The CASE For Moral Clarity 25-28 (2009).

${ }^{107}$ Ethan Bronner, Israel Poised to Challenge a U.N. Report on Gaza, NEW YoRK TIMES, Jan. 23, 2010, available at http://www.nytimes.com/2010/01/24/world/middleeast/24goldstone.html.
} 
law. It bears no repeating that the commission of war crimes must be subjected to the strongest possible condemnation. If any soldier intentionally targeted Palestinian civilians, we must condemn him in the same manner that Hamas is condemned for targeting Israeli civilians.

Rogue soldiers are a fact of war. No matter how exacting military discipline, there will always be a soldier who sees war as an opportunity to release his own brutality. Recently, an American Private was convicted of murdering four innocent civilians while on duty in Iraq. ${ }^{108}$ This does not mean, however, that it is the policy of the American forces to murder civilians. Yet the Goldstone Report takes the alleged instances of Israeli soldiers intentionally targeting civilians and claims it was the policy of Israel to intentionally target civilians. There is simply no evidence to support this illogical conclusion.

To its discredit, the Goldstone Report treats many complex and nuanced military, moral, and legal issues in an overly simplistic manner. The question of who is a civilian, for instance, is generally relegated to a footnote. ${ }^{109}$ This is, of course, a highly complex issue, especially in the context of fighting a terrorist enemy embodied in a quasigovernment. It is intellectually dishonest to say that the question of who is a civilian is a black and white matter. There is no moral equivalence between bombing a home containing a harmless Palestinian baby and bombing a home in which the IDF knows a Palestinian 'civilian' has willingly stored Hamas rockets. Reasonable people must recognize that there is a "continuum of civilianality."110 On one end of this continuum are those who send rockets into Israel. On the other end are those innocents who do not contribute in any way to the Hamas terrorist enterprise. At various points along the continuum are those who willingly store rockets for Hamas, who willingly provide Hamas with expertise in making rockets, and who willingly allow themselves to be used as human shields. Simply listing the numbers of civilians killed during the operation does not recognize that the casualties are distributed across this continuum.

The Supreme Court of Israel has grappled with these questions at length. Contrary to the Goldstone Report's claim, ${ }^{111}$ Israel recognizes article 51(3) of the Geneva Convention's First Protocol ("Civilians shall enjoy the protection afforded by this section, unless and for such time as they take a direct part in hostilities") as binding customary international law in its entirety. ${ }^{112}$ This internationally recognized articulation of civilian status, however, is not self-defining. As Justice Aharon Barak wrote, "[W]ithout a comprehensive and agreed upon customary standard, there is no escaping going case by

\footnotetext{
${ }^{108}$ James Dao, Ex-Soldier Gets Life Sentence for Iraq Murders, NEW YoRK TIMES, May 21, 2009, available at http://www.nytimes.com/2009/05/22/us/22soldier.html.

${ }^{109}$ Goldstone Report note 289.

110 See Alan Dershowitz, PreEmption: A Knife that Cuts Both Ways 229-230 (2006).

111 Goldstone Report note 289.

${ }^{112}$ HCJ 769/02 Public Committee Against Torture v. Israel (Israel 2006) ๆ 38, available at http://elyon1.court.gov.il/Files_ENG/02/690/007/A34/02007690.A34.pdf(“As we have seen, all of the parts of article 51(3) of The First Protocol reflect customary international law, including the time requirement.")
} 
case...."113 The Court, for instance, has determined that one who contributes money to a terrorist organization maintains the protection of civilian status, but that one who willingly acts as a human shield forfeits his civilian status. ${ }^{114}$ These are profound moral and legal questions. Reasonable people can disagree. Rather than explore these issues, however, the Goldstone Report ignores the complexity. It does not mention the possibility of differences along the "continuum of civilianality." It does not even ask how 'civilian' is defined in its oft-quoted casualty figures. As with the question of who is a civilian, the report reduces the nuances entailed in the proportionality question to simplicity. Although the report quotes a statement inquiring "to what extent is a military commander obliged to expose his own forces to danger in order to limit civilian casualties," 115 it simply quotes that the answer is very difficult to determine. ${ }^{116}$ Difficult indeed! It is a small wonder, then, that in almost every instance the report condemns Israel for making the incorrect judgment. ${ }^{117}$ The report completely ignores the tortured Israeli debate over whether and to what extent a democracy can value the lives of its soldiers over the lives of enemy civilians. Prof. Asa Kasher of Tel Aviv University claims that "There is no army in the world that will endanger its soldiers in order to avoid hitting the neighbors of an enemy or terrorist." 118 As such, he believes Israel should privilege the live of her soldiers over the lives of civilians. Prof. Halbertal disagrees. He writes, "It is wrong to give the commanding officer a blank check to shoot anytime his soldiers are at probable risk - but he must be given the means of protecting them as well."119 Reasonable people can disagree on these questions, but the Goldstone Report leaves no room for nuance. It condemns Israel at every turn. As Prof. Halbertal writes, "These are not simple issues....They are the occasions of deep moral struggle, because they are matters of life and death. If you are looking for an understanding of these issues, or for guidance about them, in the Goldstone Report, you will not find it."120

Goldstone and his colleagues were criticized for their black and white views on these matters at an expert discussion sponsored by the respected think tank Chatam House. The meeting concluded, "There is a...difficulty with international humanitarian law; the rules can be subject to different interpretations. A commission should tease out these legal issues and should make its view clear on the interpretation it favours. The Goldstone Report does not set out in detail its interpretation of the law in order to determine which facts are relevant to determine whether a target was legitimate or not. It did not need to express a definite view in the way that a court should, but merely needed to record that different interpretations exist on a given point, and indicate the facts which

${ }^{113}$ Id. $\mid 34$.

${ }^{114}$ Id. ๆ $35-36$.

115 Goldstone Report 1694.

${ }^{116} \mathrm{Id}$. 695.

${ }^{117}$ See, e.g., Id. $\uparrow \uparrow 49,697$.

${ }^{118}$ Amost Harel, The Philosopher who Gave the IDF Moral Justification in Gaza, HAARETZ, July 2, 2009, available at http://www.haaretz.com/hasen/spages/1062127.html.

${ }^{119}$ The Goldstone Illusion.

${ }^{120} I d$. 
would be relevant to a tribunal." ${ }^{21}$ That, of course, is precisely what the report failed to do. In its rush to condemn Israel, it failed to address the difficult questions faced by democracies fighting against terrorists who fire rockets from highly populated areas. Because the conclusion of the report was predetermined, there was no need for nuance.

Even before the report was issued, I urged the mission to consider the following questions and respond to them in its report:

1. What should a democracy do when terrorist groups, with widespread support from the local populations, commit the war crime of firing thousands of deadly, anti-personnel rockets at its school children, women and other civilians? What military options are available under international law to stop these crimes? Must they simply accept the rockets without responding? Or wait until one hits a school filled with children and kills hundreds?

2. Did Barak Obama incite war crimes or grave violations of human rights when he said the following in Sderot during a visit in 2008:

"I don't think any country would find it acceptable to have missiles raining down on the heads of their citizens.

The first job of any nation state is to protect its citizens. And so I can assure you that if-I don't even care if I was a politician. If somebody was sending rockets into my house where my two daughters sleep at night, I'm going to do everything in my power to stop that. And I would expect Israelis to do the same thing."

3. What have other nations, such as the United States, Great Britain and Russia done when faced with far less grave threats to its civilians in Afghanistan, Chechnya and other places?

4. What would your own nations do if any enemy whose charter calls for its destruction was firing rockets at its civilians?

5. Was British Colonel Richard Kemp, a military expert, lying when he said the following during the Gaza conflict:

"[F]rom my knowledge of the IDF and from the extent to which I have been following the current operation, I don't think there has ever been a time in the history of warfare when any army has made more efforts to reduce civilian casualties and deaths of innocent people than the IDF is doing today in Gaza."

\footnotetext{
${ }^{121}$ Chatam House, Report of an Expert Meeting which Assessed Procedural Criticisms made of the UN Fact- Finding Mission on the Gaza Conflict (The Goldstone Report) 6, Nov. 27, 2009, available at http://www.chathamhouse.org.uk/files/15572_il271109summary.pdf.
} 
If you disagree with Colonel Kemp, list the countries that have done more to protect civilians and indicate what more Israel could have done in the face of rockets being fired from behind human shields.

6. Do you dispute the fact that Hamas deliberately fired its rockets from behind human shield in an effort to provoke the Israeli military into killing Palestinian "shields?" Do you disagree with the following statement made by Fathi Hammad, a Hamas legislator:

"For the Palestinian people, death has become an industry, at which women excel, and so do all the people living on this land. The elderly excel at this, and so do the mujahideen and the children. This is why they have formed human shields of the women, the children, the elderly, and the mujahideen, in order to challenge the Zionist bombing machine. It is as if they were saying to the Zionist enemy: 'We desire death like your desire life."

7. Is it a violation of human rights to try to stop rockets that are being fired at civilians from behind human shields? If so, what should a democracy do when faced with such a situation?

8. In the civilian context, when a criminal fires from behind a hostage, and the police, in an effort to stop the shooter, inadvertently kill the hostage, it is the hostage-taker and not the policeman who is guilty of murder. Does the same rule apply when under international law? If not, why not?

I argued that no commission could credibly investigate what Israel $\mathrm{did}$, unless it first set out with clarity what it believed Israel should have done and could have done under international law to prevent Hamas rockets from continuing to target a million Israeli civilians. I said that a United Nations Investigation of Israel - in the face of that body's absolute refusal to investigate Russia, China, Zimbabwe, Iran and so many other countries that routinely violate human rights in an egregious manner-would constitute a major victory for the Hamas double war crime strategy of targeting Israeli civilians from behind Palestinian human shields. It would send a powerful message to all terrorist groups that provoking democracies into responding to attacks on its civilians will result in United Nations condemnation. ${ }^{122}$

\footnotetext{
122 The Goldstone Report is also a barrier to peace. Israel withdrew from the Gaza Strip with the expectation that its southern border would be peaceful. When it was forced to militarily enforce a peace through Operation Cast Lead, the Goldstone Report unequivocally condemned its actions. Israelis now know that if a West Bank withdrawal is greeted with rockets, they must either live with attacks on their major population centers or face worldwide condemnation by enforcing a peace. Neither option is desirable. Israel is therefore much less likely to withdraw from the West Bank. See Alan Dershowitz, Goldstone Report is Barrier to Peace, HuffingtonPost.COM, Sept. 22, 2009, available at http://www.huffingtonpost.com/alan-dershowitz/goldstone-report-is-a-bar_b_294493.html.
} 
I called for the international community, led by the experts who were appointed to investigate Israel, first to decide what the appropriate response is for democracies faced with attacks on its civilians by terrorists who hide behind their own civilians. Only after it is first decided, in a neutral manner, what rules of self-defense should apply to all democracies faced with terrorism by those who hide behind civilians, could an independent body then credibly apply these standards to the actions of a particular country.

The Goldstone Report did not address any of these issues. Instead, it simply condemned Israel without suggesting what lawful steps Israel could have taken to protect its civilians from Hamas rockets. In his public appearances defending the report, Goldstone has suggested that Israel could have sought protection from the United Nations, as if Israel had not repeatedly been rebuffed by that body. When asked what Israel should have done to prevent rocket attacks, Goldstone said, "Well, it could have used greater pressure by diplomatic means. They could have used the security council for that purpose." 123 Israel did go to the United Nations for help and sent tens of letters informing the security council of the continued attacks on its territory. ${ }^{124}$ If going to the United Nations failed (which, of course, it did) he said that Israel could have used commando operations or targeted killings of terrorists - actions for which Israel has been repeatedly condemned by United Nations organs. The question remains unanswered, what could Israel have done to protect its civilians without running afoul of the Goldstone Report's conception of international law? (The realistic answer is "nothing.")

\section{GoldSTONE: Hamas Does Not Use Human SHIELDS}

The reports "findings" that Hamas fighters do not wear civilian clothes in order to hide among the civilians and that they do not store weapons in mosques or use human shields, tells us more about the composition and bias of those who wrote the report than it does about the truth of these conclusions. ${ }^{125}$ The evidence is overwhelming, indisputable, and widely accepted by all people of good will that Hamas does: 1 . Deliberately have its fighters wear civilian clothes so as to make them indistinguishable from the regular population; 2 . That it does demand that women and children serve as human shields and assemble at houses that are appropriate military targets; 3 . That Hamas fighters deliberately fire rockets from near schools, mosques, and other civilian buildings; 4 . That Hamas uses mosques and other civilian buildings and homes to store weapons; and 5. That Hamas deliberately does all these for the very purpose of provoking Israel into taking military actions that will result in the deaths of Palestinian civilians so that Hamas can then complain to the media and to human rights and governmental organizations. No reasonable person could dispute this reality. Yet the report found "no evidence" that any of these well known facts were true. This tells us a great deal about the methodology used to gather evidence. If in fact, they found no evidence of such actions, it is for

\footnotetext{
${ }^{123}$ Tikkun's Interview with Judge Richard Goldstone, TIKKUN.COM, available at http://www.tikkun.org/article.php/20091002111513371.

${ }^{124}$ THE OPERATION IN GAZA: FACTUAL AND LEGAL ASPECTS $9 \uparrow$ 52-54.

${ }^{125}$ It is worth noting here that the entire report does not mention the word "terrorism" and "Hamas" in the same sentence.
} 
several reasons: 1. Hamas controlled their access to facts by selecting the areas they could investigate; 2 . Hamas controlled the testimony that they received from Palestinians on the ground; 3 . Hamas concealed and or destroying incriminating evidence; and 4. the members of the Mission closed their eyes to such evidence or refused to look for it in readily available public sources.

It is important to convey the exact nature of the report's findings on Hamas. In the following sections I will show that in each and every instance the Mission's findings either understate the nature of Hamas actions or, more often than not, come to conclusions that are completely at odds with hard evidence easily available in the public domain. ${ }^{126}$ In the final section I will demonstrate the report's deep evidentiary bias in inferring criminal intent against Israel but not Hamas.

\section{A. Militant Activity in Residential Areas}

The report concluded, in overtly tepid terms, that militants fired rockets from urban and residential areas. Here are the report's half-hearted findings:

"In view of the information communicated to it and the material it was able to review, the Mission believes that there are indications that Palestinian armed groups launched rockets from urban areas.",127

"For the present purposes, it suffices to say, that, in some of the cases, there was evidence, of the presence of Palestinian armed groups in residential areas." 128

The very language indicates bias. The Mission only "believes" that there are "indications" of firing from urban areas. It only "suffices to say" that "in some of the cases" there "was evidence." Compare this language to conclusions regarding Israeli actions where the Mission noted that there was "no doubt" of Israeli intentions and that the Mission's conclusions were "firmly based in fact." "129 The reality is that there is far more conclusive, self-proving and undisputed evidence that "Palestinian armed groups launched rockets from urban areas" than that it was the policy of Israel to kill civilians. But a reader would not know that from reading the carefully selected words of the report.

Before moving on to discuss the actions of militants in schools, mosques, and around hospitals, let us first pause to describe the actual nature of militant operations in residential areas. The hard evidence is incontrovertible that at every point of the conflict, Gaza militants consistently used residential and urban areas to launch attacks and to store their weapons, gravely endangering the lives of nearby Palestinian civilians. Here is what Amnesty International, certainly no friend of Israel, wrote about Hamas tactics:

\footnotetext{
${ }^{126}$ Much of the evidence in this section is cited in THE OPERATION IN GAZA: FACTUAL AND LEGAL ASPECTS. The Mission was not only was in possession of this report, but as noted above, cited it over 50 times.

${ }^{127}$ Goldstone Report $\ 452$.

${ }^{128} \mathrm{Id}$. 455.

${ }^{129}$ Id. ๆๆ 1884, 1895.
} 
"Hamas and other groups generally store weapons in civilian areas and there is no reason to believe that it was any different during Operation 'Cast Lead'. By doing so, it rendered such locations possible targets of attack and therefore exposed civilians who may have been present to risk." 130 The Los Angeles Times reported that during Operation Cast Lead “even many purely civilian neighborhoods aren't safe because Gaza militants often fire rockets from such areas...."131

There is specific photographic and video evidence of Hamas forces using residential areas as staging grounds for attacks. The IDF posted a January 8, 2009 aerial video of a militant setting an improvised explosive device and then climbing into a house where, when approached by the IDF, civilians began waving white flags. ${ }^{132}$ Other videos show: on December 30, 2008 Israeli forces destroying smuggling tunnels in the immediate vicinity of homes, with multiple secondary explosions indicating presence of rockets; ${ }^{133}$ on January 6, 2009, a house struck by Israeli fire, followed by multiple secondary explosions, indicating storage of hidden rockets, and an armed rocket launcher located between homes; ${ }^{134}$ and on January 7, 2009, an anti-aircraft gun positioned on a civilian building and a mortar being fired from a residential rooftop. ${ }^{135}$ The IDF also posted photos showing an underground rocket launch pad located in a residential area ${ }^{136}$ and weapons, including grenades, stored in a house during Operation Cast Lead. ${ }^{137}$ The Israeli NGO Intelligence and Terrorism Information Center has published a report documenting even more photographic evidence of residences being used to store, fire, and manufacture weapons. ${ }^{138}$ A video from Al-Aqsa TV on January 6, 2009 clearly shows men firing mortars from a civilian area in Gaza. ${ }^{139}$ Here are two photographs showing rockets fired from densely populated areas during Operation Cast Lead. ${ }^{140}$

\footnotetext{
130 AMNESTY INTERNATIONAL, OPERATION 'CAST LEAD’: 22 DAYS OF DEATH AND DESTRUCTION ROCKETS 75 (2009), available at http://www.amnesty.org/en/library/asset/MDE15/015/2009/en/8f299083-9a744853-860f-0563725e633a/mde150152009en.pdf.

${ }^{131}$ Ahmed Burai \& Jeffrey Fleishman, Calls for Gaza Truce Mount After School Hit, Los ANGELES TIMES, Jan. 7, 2009, available via Lexis.

${ }^{132}$ IDF Spokesperson's Unit, Hamas Terrorist Hides Behind White Flag Gaza 8 January 2009, posted Aug. 13, 2009, available at http://www.youtube.com/watch?v= uOug-mN3Tw.

${ }^{133}$ IDF Spokesperson's Unit, Israeli Air Force Destroys Weapons Smuggling Tunnels 30 Dec. 2008, posted Dec. 30, 2009, available at http://www.youtube.com/watch?v=v2Tc-B563ww.

${ }^{134}$ IDF Spokesperson's Unit, Hamas Militants and Weapons in Urban Gaza Hit by Israel Air Force 6 Jan. 2009, posted Jan. 6, 2009, available at http://www.youtube.com/user/idfnadesk\#p/u/32/n2m4HbiIKKA.

${ }^{135}$ IDF Spokesperson's Unit, Precision Airstrikes on Hamas Terror Targets 7 Jan. 2009, posted Jan. 7 , 2009, available at http://idfspokesperson.com/2009/01/07/precision-airstrikes-on-hamas-terror-targets-7jan-2009/.

${ }^{136}$ IDF Spokesperson's Unit, Aerial Photographs of IAF Strike on Rocket Launch Site in Gaza, posted Dec. 28, 2008, available at http://idfspokesperson.com/2008/12/28/aerial-photographs-of-iaf-strike-on-rocketlaunch-site-in-gaza/.

${ }^{137}$ IDF Spokesperson's Unit, Weapons Confiscated from the House of Terror Operative in Gaza, 15 Jan 2009, 18:20 IST, posted Jan. 15, 2009, available at http://idfspokesperson.com/2009/01/15/weaponsconfiscated-from-the-house-of-terror-operative-in-gaza-15-jan-2009-1820-ist/.

${ }^{138}$ INTELLIGENCE AND TERRORISM INFORMATION CENTER, ISRAEL INTELLIGENCE HERITAGE \& COMMEMORATION CENTER, Civilians AS HumAn SHiEldS (Feb. 18, 209), available at http://www.terrorism-info.org.il/malam_multimedia/English/eng_n/pdf/hamas_e062.pdf.

${ }^{139}$ Al-Aqsa TV, Jan. 6, 2009 available at, http://www.terrorisminfo.org.il/malam_multimedia/Hebrew/heb_n/video/h_s_video.mpeg.

${ }^{140}$ INTELLIGENCE AND TERRORISM INFORMATION CENTER, ISRAEL INTELLIGENCE HERITAGE
} 

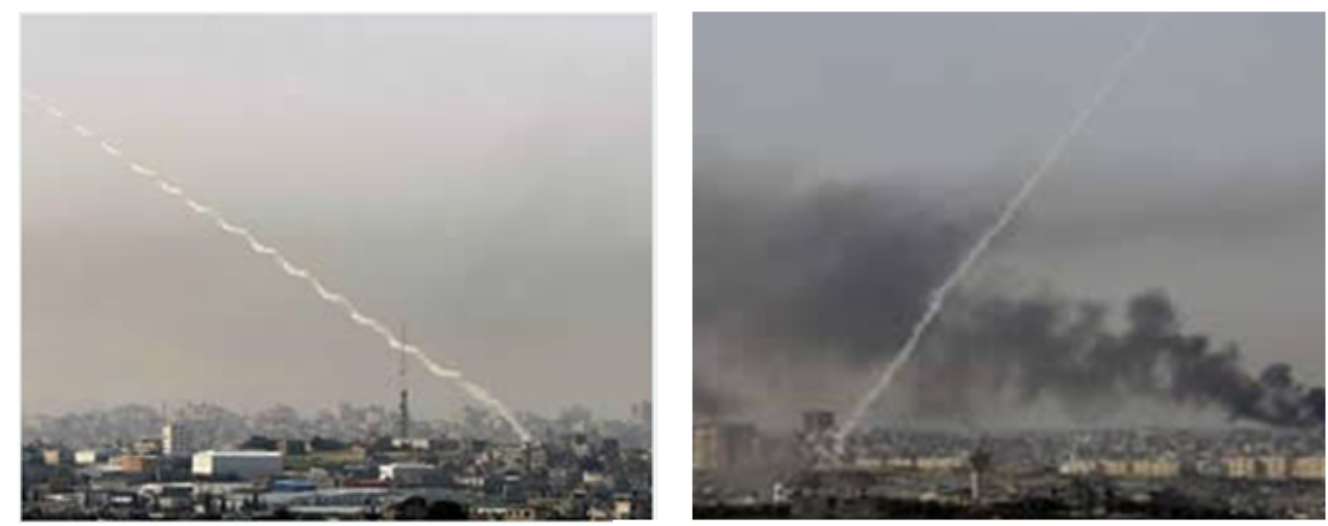

Palestinian witnesses confirm Hamas militants operating in residential areas. The Washington Post relayed the harrowing story of the Abu Nihil family:

"The [Abu Nihil] house sits next to a small sports stadium, favored by Hamas fighters as a place to launch rockets. So it was not a big surprise when Israeli warplanes fired missiles at the stadium after midnight on Dec. 29. For some reason, the first two missiles crashed into the stadium but did not explode, members of the family recalled. Still wearing their pajamas, parents and grandparents gathered the children and dashed outside. They managed to get a few blocks away by the time another missile struck the stadium. This one detonated, as designed. 'I looked back at the house,' Tarik said. 'It was on fire everywhere.' The Abu Nihils kept walking until they reached a relative's house, about a mile away. It was a difficult escape. Tarik's mother, Samira, 53, was recovering from a back operation and could barely move on her own. His sisterin-law, Raja, 24, was eight months pregnant.",141

Bassam Zakarneh of the PA's Workers' Union said, "Hamas leaders... used these $[1,400]$ martyrs as sandbags, while they hid in tunnels. They would place a missile, cover it with a tent, amid buildings with 200 children and old people, and they would launch the missile and hide."142

Newsweek reported that on January 17, 20009 at 11:30pm in the Nuseirat refugee camp, one of "Hamas's homemade Qassam rockets [was] launched into Israel—and the mobile launchpad was smack in the middle of the four buildings, where every apartment was full, most of them with newly made refugees." "143 A German paper tells the story of

\& COMMEMORATION CENTER, OPERATION CAST LEAD - UPDATE No. 15 (Jan. 15, 209), available at http://www.terrorism-info.org.il/malam_multimedia/English/eng_n/html/hamas_e042.htm.

${ }^{141}$ Craig Whitlock \& Reyham Abdel Kareem, Gaza Clan Finds One Haven After Another Ravaged in Attacks, WASHINGTON POST, Jan. 16, 2009, available via Lexis.

${ }^{142}$ Quoted in Goldstone's Gaza Report: Part I.

${ }^{143}$ Rod Nordland, Hamas and Its Discontents, NEWSWEEK.COM, Jan. 20, 2009, available at http://www.newsweek.com/id/180691/page/1v. 
Mohammed Sadala of Beit Lahia, whose home was used by Hamas during the fighting and then targeted by Israeli forces. When Sadala returned home after the fighting ended, he found the corpses of two Hamas fighters killed by Israel. In another civilian's home, militants had left a rocket launcher, assault rifle, and an ammunitions belt. "The[y, Hamas,] abused civilians' homes for their own purposes. That is not right," the anonymous civilian said. ${ }^{144}$ According to a New York Times report during Operation Cast Lead, "Shireen Shihab, 30, a resident of Gaza City, said Monday that she had seen Hamas fighters firing rockets toward Israel from a site two blocks away from her home." 145 Here is what a Palestinian source, quoted in the New York Times, said:

"This time it was different...they have more experience and they have training from Syria and Iran. They helped them rethink their strategy. They fired rockets in between the houses and covered the alleys with sheets so they could set the rockets up in five minutes without the planes seeing them. The moment they fired, they escaped, and they are very quick."

The Goldstone Report accuses Israeli soldiers of intentionally singling out civilians for death during the Abed Raboo incident and determined that "the Israeli armed forces were not engaged in combat or fearing an attack at the time of the incident." ${ }^{147}$ Yet here is what a Time reporter wrote, "Most residents of Jebel al-Kashif claim there were no Hamas fighters in the area at the time of the alleged incident [Abed Raboo], but a middleaged farmer in a battered army jacket took me aside and said, in a near whisper, that Hamas had been firing rockets from the vicinity of where the episode took place." ${ }^{\prime 48}$

Here is what Italian reporter Lorenzo Cremonesi reported about the situation during Operation Cast Lead:

“"Get away! Get away from here! Do you want the Israelis to kill everyone? Do you want our children to die under the bombs? Take your missiles and weapons away,' the inhabitants of the Gaza Strip yelled at the Hamas militants and their allies in Islamic Jihad. The more courageous were organized and blocked the entrances to their courtyards and locked the doors to their buildings, barricading quickly and furiously the stairs to the highest rooftops. But for all of that the guerrillas didn't listen to anyone. 'Traitors, collaborators with Israel, spies of Fatah, cowards! The soldiers of the holy war will punish you. And in any case you will all die, like us. Fighting the Zionist Jews we are all destined for paradise. Do you not wish to die with us?"'

\footnotetext{
${ }^{144}$ Ulrike Putz, 'Who Has Won Here?', SPIEGEL, Jan. 23, 2009, available at http://www.spiegel.de/international/world/0,1518,603203,00.html.

${ }^{145}$ Taghreed El-Khodary \& Isabel Kershner, Warnings Not Enough for Gaza Families, NEW YORK TIMES, Jan. 5, 2009, available at http://www.nytimes.com/2009/01/06/world/middleeast/06scene.html?em.

${ }^{146}$ Ethan Bronner, Parsing Gains of Gaza War, NEW YORK TIMES, Jan. 18, 2009, available at http://www.nytimes.com/2009/01/19/world/middleeast/19assess.html.

${ }_{147}$ See Goldstone Report $\uparrow \uparrow 778,812$.

${ }^{148}$ Tim McGirk \& Jebel Al-Kashif, Voices from The Rubble, TIME, Jan. 29, 2009, available at http://www.time.com/time/magazine/article/0,9171,1874850,00.html.
} 
"This is what they yelled furiously as they broke down doors and windows, hiding themselves on high floors, gardens, using ambulances and barricading themselves near the hospitals, schools and buildings of the UN. In extreme cases the [Hamas militants] shot those who sought to block them from their streets and houses to save their own families, or they beat them savagely." 149

Cremonesi also reported that two Gaza residents told him, "The Hamas militants looked for good places to provoke the Israelis. They were usually youths, 16 or 17 years old, armed with submachine guns. They couldn't do anything against a tank or jet. They knew they were much weaker. But they wanted the [Israelis] to shoot at the [the civilians'] houses so they could accuse them of more war crimes." ${ }^{150}$ Cremonesi explained, "It was difficult to get these testimonials. In general, fear of Hamas prevails and ideological taboos, fed by this century of wars with the 'Zionist enemy,' reign. Anyone who tells a different version than the story imposed by the Muhamawa (resistance), is automatically an Amil (collaborator), and risks his life."151

An Islamic Jihad newspaper boasts:

"There is no visibility of the men of the resistance in the streets of the [Gaza] strip. No one sees their known means of transportation, and even light weapons can no longer be seen with people publicly in the Gaza Strip. The resistance is totally even as its actions are felt. Anti-aircraft artillery fires on the aircraft without them knowing the location. The whereabouts of rockets launched from the heart of the strip cannot be seen or known until they're shot.... The residents of the Gaza Strip were surprised with the rockets of the resistance being fired from the heart of the cities of the Gaza Strip, without seeing how the launchers were put up, or their place, in order for deception to prevent exposure to the Israeli intelligence planes of the place of the firing of the rockets.... According to medical sources, the number of martyrs and wounded of the warriors of the Palestinian resistance are few in comparison to the number of civilian martyrs who were killed since the start of the Israeli war on Gaza, except for the large number of Palestinian policemen who were martyred on the first day...."

The evidence is clear and incontrovertible. In light of the evidence, how can the report possibly express in such halfhearted terms that there merely "are indications" Hamas used residential areas to fire rockets at Israeli civilians?

\section{B. Militant Activity in Schools and Hospitals}

Although half-heartedly accepting the possibility that militants may have fired from "urban areas," and around hospitals, the report does not credit a clear pattern of militants using schools to launch attacks and store rockets. The report also ignores evidence that hospitals may have been used for military purposes.

\footnotetext{
${ }^{149}$ Quoted in Goldstone's Gaza Report: Part II.

${ }^{150}$ Quoted in Goldstone's Gaza Report: Part I.

${ }^{151}$ Quoted in Goldstone's Gaza Report: Part I.

${ }^{152}$ Quoted in Goldstone's Gaza Report: Part I.
} 
With regard to schools, "[T]he Mission accepted, on the basis of information in the reports that it had seen, the possibility of mortar attacks from Palestinian combatants in the vicinity of the [Jabilya] school." ${ }^{\prime 53}$ In another part of the report, the Mission writes "The Mission notes that the [IDF] attack [near the school] may have been in response to a mortar attack from an armed Palestinian group but considers the credibility of Israel's position damaged by the series of inconsistencies and factual inaccuracies." ${ }^{154}$ The hard evidence shows that there were indeed militants in the vicinity of the Jabilya school. For instance, "Two residents of the area who spoke to the Associated Press by telephone said they saw a handful of militants firing mortar shells from a street near the school."155 Another reporter claims "Local residents in the street told me that militants had been firing rockets [near the school] — as the IDF claimed - and having been targeted in retaliatory fire by the IDF, they ran down the street past the school."156 The New York Times reported, "Witnesses, including Hanan Abu Khajib, 39, said that Hamas fired just outside the school compound, probably from the secluded courtyard of a house across the street, 25 yards from the school. Israeli return fire, some minutes later, also landed outside the school, along the southwest wall, killing two Hamas fighters." 157 Although two of these three sources are cited in the report, little credence is granted to them because, according to the interviews the Mission conducted, "No witness stated that he had heard any firing prior to the Israeli armed forces' mortars landing." however, that the Mission was accompanied by Hamas security, and that civilians who spoke out against the Hamas party line likely feared reprisal.

Unsurprisingly, the report does not address Hamas' clear pattern of using schools to launch attacks. It makes a single mention of a rocket fired from a school. ${ }^{159}$ The IDF has posted video or photographic evidence showing: on January 6, 2009, the presence of an anti-tank missile in a school yard in Sajalya; ${ }^{160}$ on January 8,2009 , during the humanitarian ceasefire, three militants arming a rocket-launcher in a school courtyard; ${ }^{161}$ and on January 11, 2009, a booby-trapped school and zoo rigged with explosives. ${ }^{162}$ The

${ }^{153}$ Goldstone Report $\mathbb{\top} 446$.

${ }^{154}$ Id. $₫ 690$.

${ }^{155}$ Israel Hits Second U.N. School, Blasts Way Into Southern Gaza, FoxNEWS.COM, Jan. 6, 2009, available at http://www.foxnews.com/story/0,2933,476664,00.html.

${ }^{156}$ Jonathan Miller, Why UN 'Reversal' Over Gaza School Should be Treated with Caution, CHANNEL4.COM, Feb. 5, 2009, available at

ahttp://www.channel4.com/news/articles/world/middle_east/why+un+reversal+over+gaza+school+should+ be + treated+with+caution/2924657.

${ }^{157}$ Steven Erlanger, Weighing Crimes and Ethics in the Fog of Urban Warfare, NEW YORK TIMES, Jan. 16, 2009, available at http://www.nytimes.com/2009/01/17/world/middleeast/17israel.html?pagewanted=1\&_r=1

${ }_{158}$ Goldstone Report $\uparrow 674$.

${ }^{159} I d$. 449.

${ }^{160}$ IDF Spokesperson's Unit, Missiles found in Gaza School, 6 Jan 2009, posted Jan. 6, 2009, available at http://idfspokesperson.com/2009/01/06/missiles-found-in-gaza-school-6-jan-2009/.

${ }^{161}$ IDF Spokesperson's Unit, Hamas Rockets During Cease-Fire and From Schoolyard 8 Jan. 09, 23:26 $I S T$, posted Jan. 10, 2009, available at http://idfspokesperson.com/2009/01/10/hamas-rockets-during-ceasefire-and-from-schoolyard-8-jan-09-2326-ist/.

${ }^{162}$ IDF Spokesperson's Unit, Hamas Booby Trapped School and Zoo 11 Jan. 2009, posted Jan. 11, 2009, available at http://www.youtube.com/watch?v=uHhs9ihSmbU. 
IDF has also released aerial intelligence photographs locating a Hamas military camp approximately 27 meters from a school in the Northern Gaza Strip. ${ }^{163}$ A particularly clear video shows a rocket launcher positioned between two schools on January 18, 2009. ${ }^{164}$ Here is a sequence from the film:
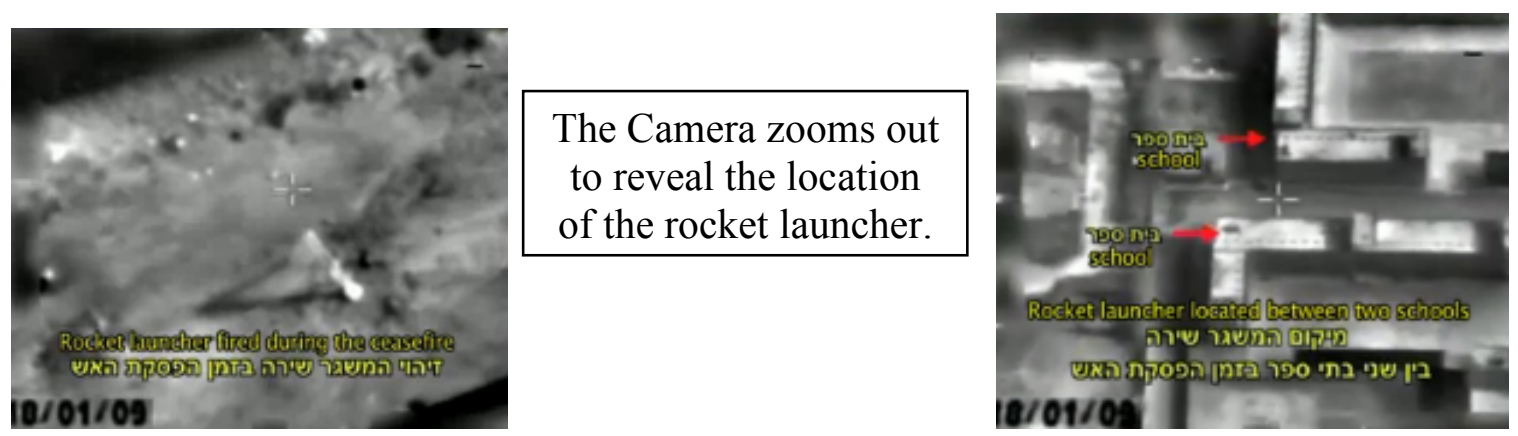

The historical record prior to Operation Cast Lead is replete with incidents of militants using schools. One of the most damning videos shows militants firing three mortar shells from an UNRWA school on Oct. 29, 2007. ${ }^{165}$

In terms of medical facilities, the report concludes, "On the basis of the investigations it has conducted, the Mission did not find any evidence to support the allegations that hospital facilities were used by the Gaza authorities or by Palestinian armed groups to shield military activities and that ambulances were used to transport combatants or for other military purposes." 166 How can the Mission claim that there is no evidence for the proposition that hospitals were not used by Hamas? The New York Times, in graphic terms, reported that armed militants in civilian clothes were present in the Shifa Hospital, summarily executing at least six civilians accused of collaboration. Even the Palestinian Authority's Ministry of Health accused Hamas of "use[ing] the medical centers, especially in a number of hospitals, [and] converting them into centers for interrogation, torture, and imprisonment." 167

The Mission, even though it is in possession of a Newsweek article suggesting otherwise, does not make factual findings whether there were militants operating in the vicinity of the Al-Quds hospital when it was attacked by Israeli forces. ${ }^{168}$ The Newsweek article reports, "In the Tal-al Hawa neighborhood nearby, however, Talal Safadi, an official in

\footnotetext{
${ }^{163}$ IDF Spokesperson's Unit, Intelligence Maps: Hamas Uses Mosques and Schools for Cover, 22 Jan 2009, 12:15 IST, posted Jan. 22, 2009, available at http://idfspokesperson.com/2009/01/22/intellignecemaps-hamas-uses-mosques-and-schools-for-cover-22-jan-2009-1215-ist/.

${ }_{164}$ IDF Spokesperson's Unit, Hamas Uses Schools and Ceasefire to Shoot Rockets at Israel, posted Jan. 19, 2009, available at http://www.youtube.com/watch?v=8LGubwghyEw\&feature=channel_page.

${ }^{165}$ IDF Spokesperson's Unit, Mortar Bombs Shot from UN School in Gaza 29 Oct. 2007, posted Jan. 1, 2009, available at http://idfspokesperson.com/2009/01/01/mortar-bombs-shot-from-un-school-in-gaza-29oct-2007/.

${ }^{166}$ Goldstone Report $₫ 487$.

${ }^{167}$ Roee Nahmias, PA: Hamas Converts Hospitals Into Jails, YNET, Feb. 7, 2009, available at http://www.ynetnews.com/articles/0,7340,L-3668018,00.html.

${ }^{168}$ See Goldstone Report $\uparrow \uparrow$ 615-623.
} 
the leftist Palestinian People's Party, said that resistance fighters were firing from positions all around the [Al-Quds] hospital.",169

The Israeli government alleged, ${ }^{170}$ with at least some independent support, ${ }^{171}$ that Hamas occupied portions of Shifa hospital during Operation Cast Lead. Israel contends that the hospital served as Hamas" "main base of operations." 172 The Mission is aware of this allegation but "did not investigate the case of al-Shifa hospital and is not in a position to make any findings with regard to these allegations." 173 Why does the Mission avoid investigating one of Israel's most serious allegations? After all, hospitals have been used in the past for military purposes. In 2007, an official from the International Committee of the Red Cross told an Australian radio show, "[W]e have noticed many armed people present inside the medical and surgical wards where even their presence have been disturbing the medical teams and frightening the patients who are treated at these hospitals. In one hospital in Biet Hanoun the hospital is out of functioning as militants sent all the medical staff home the day before yesterday causing the Hospital to stop serving the whole population of Biet Hanoun."174

The report notes the accusation that militants may have attempted to hijack ambulances, but quickly dismisses it as "the exception, not the rule." 175 In acknowledging this claim, the report cites to an article in which an ambulance driver says militants "ordered me to get them out, to put them in the ambulance and take them away....And then one of the fighters picked up a gun and held it to my head, to force me."176

\section{Militant Activity in Mosques}

The report's conclusion regarding mosques is also contradicted by hard evidence. Although the Mission possessed evidence indicating mosques were used for military purposes, ${ }^{177}$ they conclude, "The Mission is unable to make any determination on the general allegation that Palestinian armed groups used mosques for military purposes." "178 This is willful blindness, or worse, on the Mission's part. By their own admission, the Mission investigated only one instance in which the Israelis alleged mosques were used

\footnotetext{
${ }^{169}$ Rod Nordland, Hamas and Its Discontents, NEWSWEEK.COM, Jan. 20, 2009, available at http://www.newsweek.com/id/180691/page/1v.

${ }^{170}$ THE OPERATION IN GAZA: FACTUAL AND LEGAL ASPECTS $₫ 163$.

${ }^{171}$ Lorenzo Cremonesi, Così i Ragazzini di Hamas ci Hanno Utilizzato come Bersagli, CORRIERE DELLA SERA, Jan. 22, 2009, available at http://www.corriere.it/esteri/09_gennaio_21/denuncia_hamas_cremonesi_ ac41c6f4-e802-11dd-833f-00144f02aabc.shtml

172 The OpERATION IN GAZA: FACTUAL AND LEGAL ASPECTS $₫ 163$.

173 Goldstone Report 968.

${ }^{174}$ PM (ABC radio broadcast June 13, 2009), transcript available at http://www.abc.net.au/pm/content/2007/s1950580.htm.

${ }^{175}$ Goldstone Report 947.

${ }^{176}$ Jason Koutsoukis, Hamas Tried to Hijack Ambulances During Gaza War, SYDNEY MORNING HERALD, Jan. 26, 2009, available at http://www.smh.com.au/news/world/hamas-tried-to-hijack-ambulances-duringgaza-war/2009/01/25/1232818246374.html?page=fullpage\#contentSwap1.

177 Goldstone Report 964.

${ }^{178}$ Id. $₫ 486$.
} 
for military purposes. ${ }^{179}$ Had they been interested in the truth, surely the Mission would have performed more investigations, or at the very least read credible news accounts indicating militant use of mosques.

The hard evidence, had the Mission wished to credit it, proves not only that mosques were used to store weapons, but that they also served as launching grounds for rocket attacks. The New York Times reported, "Hamas fighters are also putting civilians at undue risk by storing weapons among them, including in mosques [and] schools...."180 The Los Angeles Times reported, "Every day, the Hamas rocket teams sneak through the fire and fury of Gaza to launching sites such as trucks, rooftops, school courtyards and mosques." "181 The Washington Post wrote, "Ordinarily secure places have become risky. No one seeks sanctuary in the mosques, because Hamas fighters are known to store weapons there." " the events of Operation Cast Lead and are confirmed by hard evidence provided by the IDF. Here is a video sequence showing a mortar fired from a Mosque on January 7 , 2009. ${ }^{183}$
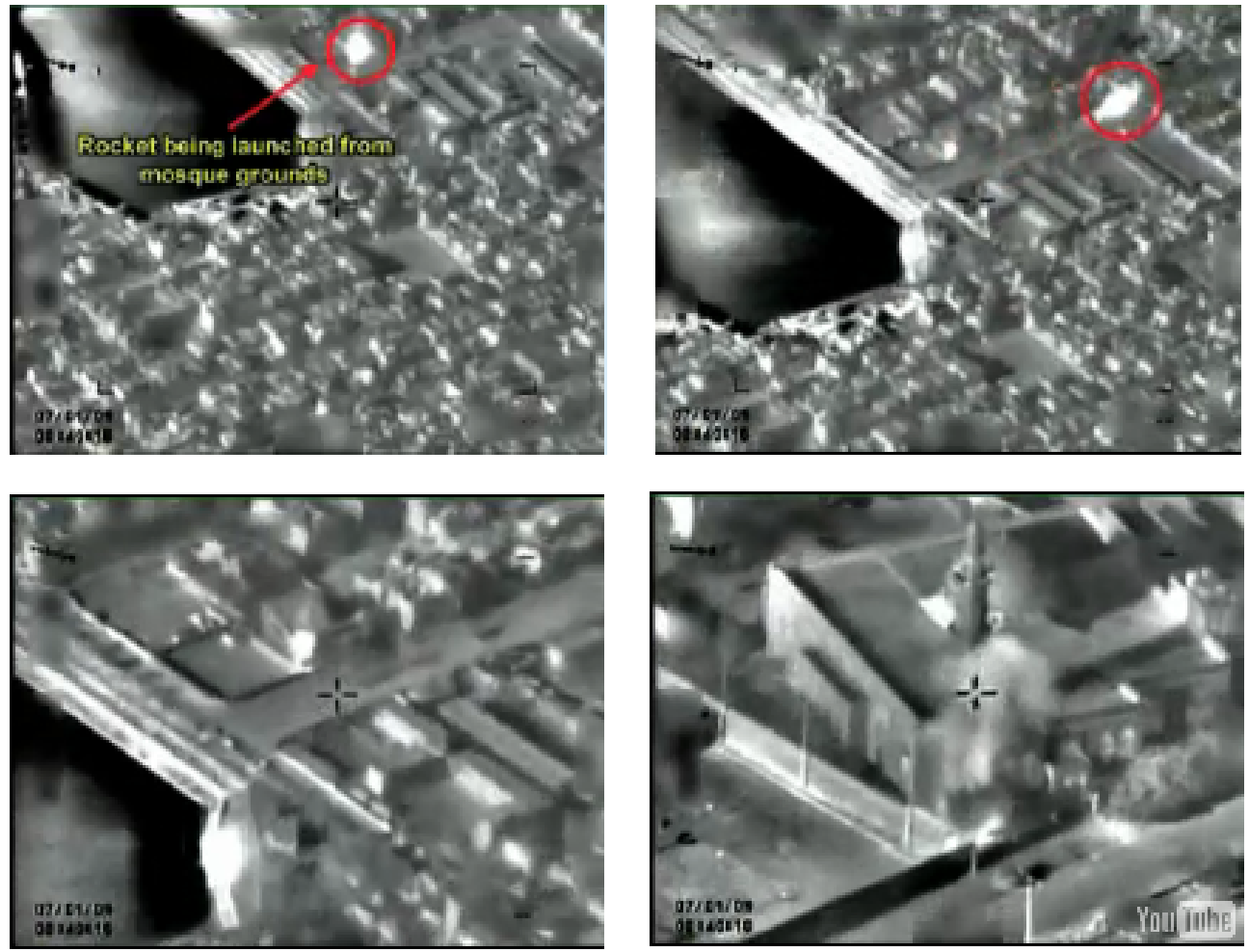

\footnotetext{
${ }^{179}$ Id. $₫ 465$.

${ }^{180}$ Steven Erlanger, Weighing Crimes and Ethics in the Fog of Urban Warfare, NEW YORK TIMES, Jan. 16 , 2009, available at http://www.nytimes.com/2009/01/17/world/middleeast/17israel.html $?$ th $=\&$ adxnnl $=1 \&$ emc $=$ th\&adxnnlx $=1232559411-5 n J Y D Z c X I s w t e d P r M v D o m A \&$.

${ }^{181}$ Sebastian Rotella, Conflict in Gaza: Hamas' Weapon of Choice, Los ANGELES TIMES, Jan. 15, 2009, available via Lexis.

${ }^{182}$ Craig Whitlock \& Reyham Abdel Kareem, Gaza Clan Finds One Haven After Another Ravaged in Attacks, WASHINGTON POST, Jan. 16, 2009, available via Lexis.

${ }^{183}$ IDF Spokesperson's Unit, Precision Airstrikes on Hamas Terror Targets 7 Jan. 2009, posted Jan. 7 , 2009, available at http://idfspokesperson.com/2009/01/07/precision-airstrikes-on-hamas-terror-targets-7jan-2009/.
} 
As the camera zooms in, the minaret of the mosque is clearly visable in the picture on the bottom right. Other video evidence shows secondary explosions erupting in two separate mosques after being hit by IDF fire on December 31, 2008 and January 1, 2009, indicating weapons were stored in the mosques. ${ }^{184}$ The IDF also posted video and photographic evidence of soldiers searching a Zeiton mosque on January 13, 2009 and finding an anti-aircraft cannon and rockets. ${ }^{185}$ More IDF Photographs show an assault rifle and ammunition hidden inside a mosque pulpit on January 15, 2009. ${ }^{186}$ On January 22, 2009 The IDF posted an aerial map locating a rocket launching site approximately 18 meters from a mosque in the Shaati refugee camp. ${ }^{187}$ Another aerial IDF intelligence map shows Hamas activity among civilian homes, schools, hospitals and mosques in Tel Zaatar. ${ }^{188}$ A particularly convincing piece of evidence is a seized Hamas intelligence map, posted on the IDF website, showing placement of improvised explosive devices directly next to civilian areas and sniper positions next to mosques. ${ }^{189}$

The report's conclusions that ignore all this evidence is not surprising, considering what one of its members, Colonel Travers said, namely that the accusation that Hamas uses mosques to store ammunition "reflects western perceptions, in some quarters that Islam is a violent religion." In other words, "political correctness" must trump hard evidence. As Groucho Marx once put it: "Who are you going to believe, me? Or your lying eyes?" Or in the present context, "my political bias or your lying videos?"

\section{Militant Uniforms}

It is widely accepted that Hamas militants often do not wear uniforms or proper insignia when attacking Israeli forces. It should come as a surprise then that "The Mission found no evidence that members of Palestinian armed groups engaged in combat in civilian dress." 190 Again, the hard evidence contradicts the report's conclusion. The New York

\footnotetext{
${ }^{184}$ IDF Spokesperson's Unit, Weapons Hidden in Mosque Neutralized by Israel Air Force 31 Dec 2008, posted Jan. 1, 2009, available at http://idfspokesperson.com/2009/01/01/weapons-hidden-in-mosqueneutralized-by-israel-air-force-31-dec-2008/; IDF Spokesperson's Office, IAF Strike on Mosque Used as Weapon Storage Site, 2 Jan 2009, posted Jan. 2, 2009, available at http://idfspokesperson.com/2009/01/02/iaf-strike-on-mosque-used-as-weapon-storage-site-2-jan-2009/. ${ }^{185}$ IDF Spokesperson's Unit, Weaponized Mosque, 13 Jan 2009, 18:30 IST, posted Jan. 13, 2009, available at http://idfspokesperson.com/2009/01/13/weaponized-mosque-13-jan-2009-1830-ist/; IDF Spokesperson's Office, Weapons Discovered in Zeitoun Mosque, 13 Jan 2009, 21:34, posted Jan. 13, 2009, available at http://idfspokesperson.com/2009/01/13/weapons-discovered-in-zeitoun-mosque-13-jan-2009-2134-ist/.

${ }^{186}$ INTELLIGENCE AND TERRORISM INFORMATION CENTER, ISRAEL INTELLIGENCE HERITAGE \& COMMEMORATION CENTER, EVIDENCE FROM OPERATION CAST LEAD SHOWS HAMAS USES MOSQUES TO STORE WEAPONS AND AS Sites LAUNCH ROCKETS AND MORTAR SHELlS (Feb. 16, 2009), available at http://www.terrorism-info.org.il/ malam_multimedia/ English/eng_n/pdf/hamas_e059.pdf .

${ }^{187}$ IDF Spokesperson's Unit, Intelligence Maps: Hamas Uses Mosques and Schools for Cover, 22 Jan 2009, 12:15 IST, posted Jan. 22, 2009, available at http://idfspokesperson.com/2009/01/22/intellignecemaps-hamas-uses-mosques-and-schools-for-cover-22-jan-2009-1215-ist/.

${ }^{188}$ IDF Spokesperson's Unit, Hamas Deployment in the Tel-Zaatar Region, available at http://idfspokesperson.files.wordpress.com/2009/01/intelmaps2.jpeg .

${ }^{189}$ IDF Spokesperson's Unit, Captured Hamas Intelligence, 9 Jan 2009, 16:26 IST, posted on Jan. 9, 2009, available at http://idfspokesperson.com/2009/01/09/captured-hamas-intelligence-9-jan-2009-1626-ist/.

${ }^{190}$ Goldstone Report $₫ 495$.
} 
Times noted during Operation Cast Lead that Hamas militants fought "in the midst of civilians, often in civilian clothing."191 'Mohammed,' a member of the Izz al-Din alQassam Brigades told The Times of London that fighters wore civilian clothes during military activities. ${ }^{192}$ The Chicago Tribune reported, "The Israeli offensive to halt Hamas rocket attacks pitted the military against gunmen fighting among civilians, often in civilian clothes themselves...." ${ }^{193}$ A video from Al-Aqsa TV on January 6, 2009 clearly shows men dressed in civilian clothes firing mortars. ${ }^{194}$ When an NPR host asked an AlJazeera reporter in Gaza City whether people would be able to distinguish militant-aged civilians and actual militants, he responded, "Certainly not. The short answer to that is no. You cannot distinguish because if you were just going to base it on looks, since the first day of the attacks, we know that a lot of the services here, the police services as well as the military factions, are not dressing in particularly identifiable uniforms. They may have done on the first couple of days, but there is no clear identifiable marker to say someone is a civilian or someone is not." "195 Talal Abu Ramah told CNN, "Now Hamas, they are under cover, all of them they are civilians now, you don't see any militants around you, even the cars...I don't know if the car in front of me or in the back of me, if it's a target or not." ${ }^{196}$ Once again the report's conclusion flies in the face of the clear and incontrovertible evidence. How can the members possibly explain these contradictions, which should be obvious to all?

\section{E. Directing Civilians to Areas to Shield Military Objectives from Attack}

One of the most serious charges against Hamas is that they directed or forced civilians to shield military objectives from attack, in violation of international humanitarian law. Despite hard evidence of this, "On the basis of the information it gathered, the Mission found no indication that the civilian population was forced by Hamas or Palestinian armed groups to remain in areas under attack from the Israeli armed forces." 197 Here again, the hard evidence points to the opposite conclusion. It proves conclusively that some civilians volunteered, some were coerced and others were forced to serve as human shields.

To begin, the evidence demonstrates a pattern of directing civilians into harm's way prior to Operation Cast Lead. For instance, in early November 2006, a group of militants in a mosque were under siege by Israeli forces. A Hamas radio station brazenly called on

\footnotetext{
${ }^{191}$ Steven Erlanger, Weighing Crimes and Ethics in the Fog of Urban Warfare, NEW YORK TIMES, Jan. 16, 2009, available at http://www.nytimes.com/2009/01/17/world/middleeast/17israel.html?th=\&adxnnl= $1 \&$ emc $=$ th\&adxnnlx $=1232559411-5$ nJYDZcXIswtedPrMvDomA\&.

${ }^{192}$ Martin Fletcher, Sheera Frenkel \& Azmi Keshawi, Gaza's Tunnels, Traps and Martyrs, THE TIMES (London), Jan. 12, 2009, available at http://www.timesonline.co.uk/tol/news/world/middle_east/ article5497340.ece.

${ }^{193}$ Joel Greenberg, Israeli Army's Conduct Questioned, CHICAGO TRIBUNE, Jan. 26, 2009, available via Lexis.

${ }^{194}$ Al-Aqsa TV, Jan. 6, 2009 available at, http://www.terrorisminfo.org.il/malam_multimedia/Hebrew/heb_n/video/h_s_video.mpeg.

${ }^{195}$ Morning Edition (NPR radio broadcast Jan. 8, 2009), transcript available via Lexis.

${ }^{196}$ Quoted in Goldstone's Gaza Report: Part I.

197 Goldstone Report $₫ 488$.
} 
Gaza women to serve as "human shields" for the militants, which many willingly did. ${ }^{198}$ On Nov. 20, 2006, Israeli forces called Hamas operative Wael Rajab to warn him that his home would be destroyed. According to the Jerusalem Post, civilians "flocked" to Rajab's home to serve as human shields and prevent the strike. ${ }^{199}$ A similar incident occurred on Nov. 18, 2006 when the head of the Popular Resistance Committees' qassam division Mohammedweil Baroud received warning his house would be destroyed. ${ }^{200}$ After Baroud rushed to a mosque to gather human shields, hundreds of people, including women and children, surrounded the house to prevent the Israeli strike. ${ }^{201}$ Before these two incidents, a Hamas preacher said, "Instead of running away, the owners [of threatened houses] must stay inside their homes and call the neighbors and as many people as possible. The human shields are the best way to protect the houses."202 Abu Mujahed, spokesperson for the Popular Resistance Committees insisted "From now on we will form human chains around every house that is threatened with demolition."

Even though the report claims that "No such incidents [of forcing/directing human shields] are alleged by the Israeli Government with regard to the military operations that began on 27 December 2008 [and t] he Mission received no reports of such incidents from other sources," 204 a simple news search reveals hard evidence that Hamas did indeed direct and force human shields during Operation Cast Lead. The Times of London tells the story of a Palestinian whose roof was scouted by militants as a sniper position prior to the operation. When fighting began, he was told by militants he was "part of the resistance" and was forced to serve as a human shield. The civilian recalls,

"They were resistance fighters. I did not want them there but they made it clear that this is where they would set up their positions. I went downstairs to wake my wife to tell her we would go to her sisters'. But they stopped us. [The militants said, ']If soldiers come, you must send your children to warn us. Tell them there is no one here and we will escape somewhere else.['] They would not listen when I told them to let my youngest children go, my family. They said no, it must look normal.",205

Wafa Kannan, of Gaza City, was lucky. The Knight Ridder wire service reported her story:

\footnotetext{
${ }^{198}$ Hanan Greenberg, Palestinians: Gunmen Flee Besieged Mosque, YNET, Nov. 3, 2006, available at http://www.ynetnews.com/articles/0,7340,L-3323131,00.html; Gaza Women Killed in Mosque Siege, BBC, Nov. 3, 2006, available at http://news.bbc.co.uk/2/hi/middle_east/6112386.stm.

${ }^{199}$ Yaakov Katz \& Khaled Abu Toameh, Gaza: Use of Human Shields Continues, JERUSALEM Post, Nov. 20, 2006, available at http://www.jpost.com/servlet/Satellite?cid=1162378435257\&pagename=JPArticle $\%$ 2FShowFull.

${ }^{200} \mathrm{Id}$.

${ }^{201} I d$.

${ }^{202} I d$.

${ }^{203} \mathrm{Id}$.

${ }^{204}$ Goldstone Report 9476.

${ }^{205}$ Sheera Frenkel, Human Shields Were Forced Into the Front Line - By Both Sides, THE TIMES (London), Feb. 2, 2009, available via Lexis.
} 
"In an apartment building across the street from Kannan and her family live four brothers who are Hamas militants. Israeli intelligence called the Hamas members to warn them that they were targets, Kannan said. Leaders at the local mosque urged neighbors to converge on the apartment building and act as human shields, she added. No one heeded the call, however, so the Hamas militants fled."206

The IDF has posted video evidence of civilians being forced or directed to serve as human shields during Operation Cast Lead. One video shows a militant launching a rocket from the roof of a home and then being escorted out by civilians. ${ }^{207}$ Another video shows a fleeing militant attempting to maneuver himself next to civilians so as to shield himself from attack. ${ }^{208}$ Yet this evidence, and much more, was ignored by the report.

\section{F. Intent}

The central issue that distinguishes the conclusions of the Goldstone Report regarding Israel and Hamas is intentionality. The report finds that the most serious accusation against Israel, namely the killing of civilians, was intentional (and deliberately planned at the highest levels). The report also finds that one of the most serious accusations made against Hamas, namely that their combatants wore civilian clothing to shield themselves from attack, mingled among the civilian populations and used civilians as human shields, was unintentional.

It must be pointed out, to begin with, that the issue of Hamas' intentions and actions with regard to the civilian shield issue is not unrelated to the issue of the IDF's intentions and actions with regard to the deaths of Palestinian civilians. If it were to turn out that there was no evidence that Hamas ever operated from civilians areas, and that the IDF knew this, then the allegation that the IDF, by firing into civilian areas, deliberately intended to kill Palestinian civilians, would be strengthened. But if it were to turn out that the IDF reasonably believed that Hamas fighters were deliberately using civilians as shields, then this fact would weaken the claim that the IDF had no military purpose in firing into civilian areas. It would also undercut the conclusion that Israel's real intention could be nothing other than its desire to kill Palestinian civilians. Moreover, if Hamas did use human shields then the deaths of Palestinian civilians would be more justly attributable to Hamas then to Israel.

Since intentionality, or lack thereof, was so important to the report's conclusions, it would seem essential that the report would apply the same evidentiary standards, rules and criteria in determining the intent of Israel and in determining the intent of Hamas. Yet a careful review of the report makes it crystal clear that its writers applied totally different standards, rules and criteria in evaluating the intent of the parties to the conflict.

\footnotetext{
${ }^{206}$ Dion Nissenbaum \& Ahmed Abu Hamda, Death Toll Rises as Israel Continues Gaza Assault, Knight Ridder wire, Dec. 29, 2008, accessed via Lexis.

${ }^{207}$ IDF Spokesperson's Unit, Cast Lead Video: Hamas Terrorist uses Children as Human Shield, posted Sept. 17, 2009, available at http://www.youtube.com/watch?v=2vHDyuSTneA.

${ }^{208}$ IDF Spokesperson's Unit, Cast Lead Video: Civilians Flee Hamas Terrorist as He Attempts to Use Them as Human Shield, posted Sept. 17, 2009, available at http://www.youtube.com/watch?v=9MPwR0 Eu32M.
} 
The report resolved doubts against Israel in concluding that its leaders intended to kill civilians, while resolving doubts in favor of Hamas in concluding that it did not intend to use Palestinian civilians as human shields. Moreover, when it had precisely the same sort of evidence in relation to both sides - for example, statements by leaders prior to the commencement of the operation - it attributed significant weight to the Israeli statements, while entirely discounting comparable Hamas statements. This sort of evidentiary bias, though subtle, and perhaps not readily apparent to the non-legal reader, permeates the entire report.

In addition to the statements of leaders, which are treated so differently, the report takes a completely different view regarding the inferring of intent from actions. When it comes to Israel, the report repeatedly looks to results and infers from the results that they must have been intended. But when it comes to Hamas, it refuses to draw inferences regarding intent from results. For example, it acknowledges that some combatants wore civilian clothes, and it offers no reasonable explanation for why this would be so other than to mingle indistinguishably from civilians. Yet it refuses to infer intent from these actions. This is crucial because the violation of international humanitarian law known as human shield use requires specific intent. ${ }^{209}$ For Hamas to be guilty of using human shields, militants not only needed to know that when they fired rockets from civilian areas, Israel was deterred from responding, but it must have been their purpose in shooting the rockets from civilian areas to deter Israel from responding or to cause Israel to kill civilians. Although the Mission, as discussed above, half-heartedly concludes that militants fired rockets from civilian areas, they refuse to believe that this was done with the purpose of rendering such areas immune from attack. Here are the report's words: "On the basis of the information it gathered, the Mission finds that there are indications that Palestinian armed groups launched rockets from urban areas. The Mission has not been able to obtain any direct evidence that this was done with the specific intent of shielding the rocket launchers from counterattacks by the Israeli armed forces." ${ }^{210}$ Notice the use of the words direct evidence. As discussed in section I above, the report used five categories of evidence to conclude Israel had a policy of intentionally killing civilians: military leader statements, political leader statements, circumstance (Israel's use of advanced weaponry ), result (the sheer number of civilian deaths), and alleged related actions (destruction of infrastructure). None of these categories constitute direct evidence of intent. The report does not explain why it requires direct evidence to infer Hamas intent but is content to rely on extremely weak circumstantial evidence to infer Israeli intent.

\footnotetext{
${ }^{209}$ See Goldstone Report 9 493. Article 51(7) of the First Protocol, the prohibition on use of human shields, is part of the basis for Art. 8(2)(b)(xxii) of the Rome Statute of the International Criminal Court. The second element of Art. 8(2)(b)(xxii) requires that "The perpetrator intended to shield a military objective from attack or shield, favour, or impede military operations." An ICRC commentary reads, "Bearing in mind that the aim of the prohibition is to protect civilians and other protected persons from the effects of attacks, the decisive element of the crime would be the intention to shield. Therefore, Element 2 was adopted....The way it is drafted, it may be qualified as a specific intent requirement." KNUT DÖRMANN, ELEMENTS OF WAR CRIMES UNDER THE ROME STATUTE OF THE INTERNATIONAL CRIMINAL COURT 344-348.

${ }^{210}$ Goldstone Report 9482.
} 
The Mission was in possession of Hamas statements that strongly suggested intent, but refused to credit them. As described in section I of this paper, the report quoted a Hamas political leader who said, "For the Palestinian people, death has become an industry, at which women excel, and so do all the people living on this land....This is why they have formed human shields of the women, the children, the elderly, and the mujahideen, in order to challenge the Zionist bombing machine."211 The Mission responded that the "it does not consider it [the quote] to constitute evidence that Hamas forced Palestinian civilians to shield military objectives against attack."212 This statement is used in the section of the report investigating whether militants forced civilians to go to certain areas for the purpose of providing cover. This is a distinct inquiry from whether militants had the specific intent of shielding themselves when operating in areas that happened to be occupied by civilians. The quote is certainly relevant to this later inquiry, as it tends to show the Hamas ideology that using human shields is not only permitted, but admirable. Nonetheless, the report refuses to infer intent on the basis of this statement.

The Mission is also in possession of another statement from a Palestinian militant that suggests intent. The fighter's paraphrased words were that he launched attacks from civilian areas "in the hope that nearby civilians would deter Israel from responding." 213 Unlike any of the statements made by Israeli officials discussed in section I, this statement actually is direct evidence of intent. Astonishingly, the report does not credit the statement because another fighter said, "[T] he most important thing is achieving our military goals. We stay away from the houses if we can, but that's often impossible."214 The Mission found that this quote "suggests the absence of intent." 215 The report does not even consider that some fighters possessed the requisite intent and others did not, or that some were just towing the party line when speaking with investigators. Instead, it uses the statement of the second militant to discredit the statement of the first militant. There were of course many comparable statements by Israeli officials that could have been used to impeach the ones selected by the report. It is telling of the Mission's bias that the report goes so far to present a balanced view of Hamas militants but selects for publication only the most hyperbolic and extreme statements of Israeli political officials.

Highly relevant to the report's conclusion that militants did not intend for their actions to shield themselves from counterattack is that the Mission was "unable to make any determination on the general allegation that Palestinian armed groups used mosques for military purpose," 216 "did not find any evidence to support the allegations that hospital facilities were used by the Gaza authorities or by Palestinian armed groups to shield military activities," 217 did not find evidence "that ambulances were used to transport combatants or for other military purposes," 218 and did not find "that Palestinian armed groups engaged in combat actives from United Nations facilities that were used as

\footnotetext{
${ }^{211} I d .9477$.

${ }^{212} I d$. 478.

${ }^{213} I d$. 453.

${ }^{214} \mathrm{Id}$.

${ }^{215} \mathrm{Id}$.

${ }^{216} \mathrm{Id}$. 486.

${ }^{217}$ Id. 487.

${ }^{218} I d$.
} 
shelters during the military operations." 219 As discussed above, however, there is hard evidence that Hamas did operate in mosques and, at the very least, near hospitals.

Evidence of circumstance (precise weaponry) was used to prove Israeli intent. Regarding Hamas, the evidence of circumstance is even stronger in inferring intent. It is beyond obvious that militants do not fire rockets in the vicinity of mosques or hospitals because it is easier to launch rockets near community institutions. Rather, they do so only because of the special protections afforded to hospitals and religious centers in war. The only purpose in firing from these facilities is to shield militants from counter-attack. There simply is no other explanation.

In refusing to conclude that Hamas operated in mosques and hospitals during Operation Cast Lead, the Mission discounted photographic and video evidence on the basis that it "refer[s] not to the December 2008-January 2009 period, but to previous alleged instances of firing rockets from Gaza." 220 Dismissing evidence prior to Operation Cast Lead is the modus operandi to the Mission when it comes to Hamas. In determining that Hamas did not direct civilians to areas to shield military objectives from attack, the report also dismisses clear evidence in its possession that Hamas directed civilians to areas to shield military objectives from attack in 2007. Because the event did not occur during Operation Cast Lead, the Mission deemed it utterly irrelevant. ${ }^{221}$ There are numerous problems with this misuse of evidence. In the first place, the report placed great weight on hyperbolic statements made by Israeli military officials years before Operation Cast Lead. Many of them were made in the context of the very different war fought against Hezbollah in Lebanon during 2006. Second, and even more important, is the fact that Israel's military planning, which the report focuses on, took place well in advance of the commencement of Operation Cast Lead. It is highly relevant to the intention of Israeli planners that they have hard video, photographic and testimonial evidence of Hamas fighters firing rockets from behind human shields. Even if no rockets were fired from behind human shields during Operation Cast Lead - an absurd conclusion contradicted by massive evidence - it would still be relevant to Israel's intentions that the planners were aware of Hamas' long term modus operandi: namely, to fire their rockets from behind human shields in densely populated civilian areas. Further, past actions would be important for inferring the intentions of Hamas. It is reasonable to suppose that militant mental state does not change over time vis-à-vis launching attacks from civilian areas. If militants were willing to fire from a mosque or behind a forced civilian shield two years earlier to avoid counterattack, it is likely that when they later fire rockets from residential areas, that are doing so to shield themselves from counterattack.

This study ends with refusal to infer intent that is most absurd and therefore most telling of the report's bias. The Mission wrote, "While reports reviewed by the Mission credibly indicate that members of Palestinian armed groups were not always dressed in a way that distinguished them from civilians, the Mission found no evidence that Palestinian combatants mingled with the civilian population with the intention of shielding

${ }^{219}$ Id. $₫ 485$

${ }^{220}$ Id. 451.

${ }^{221}$ See Id. 476. 
themselves from attack." ${ }^{, 22}$ Prof. Halbertal succinctly disposes of this maddening reasoning: "The reader of such a sentence might well wonder what its author means. Did Hamas militants not wear their uniforms because they were inconveniently at the laundry? What other reasons for wearing civilian clothes could they have had, if not for deliberately sheltering themselves among the civilians?"223 The report does not address this question, because if it did, it would have had to reach a conclusion that would have undercut the basic thrust of the report: namely that Israel deliberately shot at civilians, rather than at terrorists who deliberately wore civilian clothing and hid among the civilian population.

\section{CONCLUSION: A WASTED OPPORTUNITY AND A BIASED REPORT}

There are six possible roles that an investigative commission could have performed. Each requires different qualifications and levels of neutrality.

1. To gather evidence of all possible allegations and accusations leveled by each side against the other. No effort is made to evaluate the credibility of these allegations. The sole function is to gather the accusations and make them public so that the other side can respond. To conduct such an evidence-gathering investigation requires that the investigators have the trust of those who they are interviewing. It also requires a degree of neutrality in making certain that a fair sampling of accusations is gathered and that the information is not skewed in one way or another.

2. To assess the credibility of those making the accusations. This requires cross examination of the accusers and subjecting the accusations to crosschecking against other evidence. It also requires that those evaluating credibility be absolutely neutral and objective and have no predisposition to believing one side over the other.

3. To gather evidence of the intentions of the various actors. This is an extremely difficult task that requires access to statements both public and private of both sides. This function does not require assessment of credibility of the evidence but rather merely its gathering to present publicly so that the other side can respond.

4. To assess the credibility of evidence regarding intent and to arrive at conclusions. This too requires absolute neutrality and objectivity.

5. To make legal findings regarding the actions and intentions of both sides. This requires sophisticated legal expertise and experience.

6. To make an overall political assessment of the nature of the conflict, its history and its current status. This requires historical and diplomatic expertise and neutrality.

${ }^{222} I d$ ๆ 483.

${ }^{223}$ The Goldstone Illusion. 
Had the Goldstone report limited itself to the first function-gathering testimony and physical evidence of the actions of both sides without assessing credibility-it would have performed a useful function. The factual allegations in the report include serious charges against both sides that require serious investigations and responses. The Israeli military is undertaking precisely such an investigation, and I hope there will be an independent civilian investigation as well. There is no likelihood that Hamas will conduct any credible inquiry, since it has no history of, or process for, doing so.

The report goes well beyond simply gathering testimonies. It purports to assess credibility, determine intentions and arrive at both legal and political conclusions. The members of this commission not only lack the expertise to engage in these latter assessments, but even more important they lack the neutrality and objectivity. As Goldstone himself has acknowledged, if this were a court of law, "there would have been nothing proven," 224 and at least one of its members would have been disqualified as a result of pre-existing bias.

Beyond its limited function of gathering testimonies from residents of Gaza, the Goldstone mission represents a wasted opportunity for an objective group of real experts to consider the difficult moral, military, political and legal issues presented by the situation in Gaza. The report, commissioned by an organization with a long history of anti-Israel bigotry, and written by biased "experts," with limited experience and a preordained result, is one-sided and wrong in its fundamental conclusions. This should not be surprising since conclusions can be no better than the methodology employed, and the methodology employed in this report is fundamentally flawed. ${ }^{226}$

So now it is up to Richard Goldstone to explain the evidentiary bias that is so obviously reflected in the report. The burden is on him to justify the very different methodologies used in the report to arrive at its conclusions regarding the intentions of Israel and the intentions of Hamas. Failure to assume that burden will constitute an implicit admission that the conclusions reached in the Goldstone Report are not worthy of consideration by people of good will. I await his response.

\footnotetext{
${ }^{224}$ Gal Beckerman, Goldstone: 'If This Was a Court Of Law, There Would Have Been Nothing Proven', THE FORWARD, Oct. 16, 2009, available at http://www.forward.com/articles/116269/.

${ }^{226}$ This analysis does not deal with the widespread criticism of the original mandate under which the Mission was established. See, e.g., Goldstone's Gaza Report: Part II. Nor does it repeat what I have written elsewhere about the extensive review process that Israel has of military actions, including by the Judge Advocate General, who is accountable to the Minister of Defense and not to the military chain of command, as well as the Supreme Court, which frequently intervenes even in ongoing military engagements. See, e.g., Alan Dershowitz, The CASE FOR MORAl Clarity 61-62.
} 